medRxiv preprint doi: https://doi.org/10.1101/2021.10.31.21265722; this version posted November 1, 2021. The copyright holder for this preprint (which was not certified by peer review) is the author/funder, who has granted medRxiv a license to display the preprint in

All rights reserved. No reuse allowed without permission.

\title{
A blood-based miRNA signature predicts immunotherapy efficacy in advanced stage non-small cell lung cancer
}

Timothy Rajakumar ${ }^{1}$, Rastislav Horos ${ }^{1}$, Julia Jehn ${ }^{1}$, Judith Schenz ${ }^{2}$, Thomas Muley ${ }^{3}$, Oana

Pelea $^{4}$, Sarah Hofmann ${ }^{1}$, Paul Kittner ${ }^{1}$, Mustafa Kahraman ${ }^{1}$, Marco Heuvelman ${ }^{1}$, Tobias

Sikosek $^{1}$, Jennifer Feufel ${ }^{1}$, Jasmin Skottke ${ }^{1}$, Dennis Nötzel ${ }^{1}$, Franziska Hinkfoth ${ }^{1}$, Kaja Tikk ${ }^{1}$, Alberto Daniel-Moreno ${ }^{1}$, Jessika Ceiler ${ }^{1}$, Nathaniel Mercaldo ${ }^{5}$, Florian Uhle ${ }^{2}$, Sandra Uhle ${ }^{2}$, Markus A Weigand ${ }^{2}$, Mariam Elshiaty ${ }^{3}$, Fabienne Lusky ${ }^{3}$, Hannah Schindler ${ }^{3}$, Quentin Ferry ${ }^{6}$, Tatjana Sauka-Spengler ${ }^{4}$, Qianxin $\mathrm{Wu}^{7}$, Klaus F Rabe ${ }^{8,9}$, Martin Reck $^{8}$, Michael Thomas ${ }^{3}$, Petros Christopoulos ${ }^{3}$, Bruno R Steinkraus ${ }^{1, *}$

${ }^{1}$ Hummingbird Diagnostics GmbH, Im Neuenheimer Feld 583, 69120 Heidelberg, Germany 2Department of Anesthesiology, Heidelberg University Hospital, Heidelberg, Germany

${ }^{3}$ Thoraxklinik and National Center for Tumor Diseases (NCT) at Heidelberg University Hospital, Germany

${ }^{4}$ MRC Weatherall Institute of Molecular Medicine, University of Oxford, Oxford, United Kingdom

${ }^{5}$ Institute for Technology Assessment, Department of Radiology, Massachusetts General Hospital, Boston, United States

${ }^{6}$ Picower Institute for Learning and Memory, Massachusetts Institute of Technology, Cambridge, United States

${ }^{7}$ Wellcome Sanger Institute, Wellcome Genome Campus, Hinxton, Cambridge, United Kingdom

${ }^{8}$ LungenClinic Grosshansdorf, Airway Research Center North, German Center for Lung Research, Grosshansdorf, Germany

${ }^{9}$ Department of Medicine, Christian Albrechts University of Kiel, Kiel, Germany

*correspondence should be addressed to Bruno R Steinkraus, PhD, bsteinkraus@hb-dx.com 
medRxiv preprint doi: https://doi.org/10.1101/2021.10.31.21265722; this version posted November 1, 2021. The copyright holder for this preprint (which was not certified by peer review) is the author/funder, who has granted medRxiv a license to display the preprint in

All rights reserved. No reuse allowed without permission.

\section{Abstract}

2

3 Immunotherapies have recently gained traction as highly effective therapies in a subset of 4 late-stage cancers. Unfortunately, only a minority of patients experience the remarkable

5 benefits of immunotherapies, whilst others fail to respond or even come to harm through 6 immune related adverse events. For immunotherapies within the PD-1/PD-L1 inhibitor class, 7 patient stratification is currently performed using tumor (tissue-based) PD-L1 expression. 8 However, PD-L1 is an accurate predictor of response in only $\sim 30 \%$ of cases. There is pressing 9 need for more accurate biomarkers for immunotherapy response prediction.

10 We sought to identify peripheral blood biomarkers, predictive of response to immunotherapies 11 against lung cancer, based on whole blood microRNA profiling. Using three well characterized 12 cohorts consisting of a total of 334 stage IV NSCLC patients, we have defined a 5 microRNA 13 risk score (miRisk) that is predictive of immunotherapy response in training and independent 14 validation cohorts. We have traced the signature to a myeloid origin and performed miRNA 15 target prediction to make a direct mechanistic link to the PD-L1 signalling pathway and PD-L1 16 itself. The miRisk score offers a potential blood-based companion diagnostic for 17 immunotherapy that outperforms tissue-based PD-L1 staining. 
medRxiv preprint doi: https://doi.org/10.1101/2021.10.31.21265722; this version posted November 1,2021 . The copyright holder for this preprint (which was not certified by peer review) is the author/funder, who has granted medRxiv a license to display the preprint in perpetuity.

All rights reserved. No reuse allowed without permission.

\section{Introduction}

Recently, immune checkpoint inhibitors (ICl), also known as immunotherapies, have emerged as a breakthrough treatment for advanced non-small-cell lung cancer (NSCLC) and other cancers ${ }^{1}$. These drugs target the inhibitory interaction between immune checkpoint receptors and their ligands, for example the Programmed-Death 1 (PD-1) pathway. While originally evolved to mediate self-tolerance, certain tumors have adapted to exploit these signalling pathways and thereby escape the immune response. If efficacious, immunotherapy augments T-cell immune responses against malignant cells and can deliver unprecedented clinical benefit. However, positive responses typically occur in only a minority of patients ${ }^{2,3}$. To date, five inhibitors of the PD-1/PD-L1 axis have been approved for advanced NSCLC: of these, pembrolizumab, nivolumab and cemiplimab target PD-1, whilst durvalumab and atezolizumab target its ligand PD-L1. Besides remarkable anti-tumor activity, these drugs are also associated with characteristic (and occasionally life-threatening) side effects, particularly immune-related adverse events and hyperprogression ${ }^{4,5}$. Taken together with the significant cost of these treatments, it is vital to administer immunotherapies only to those patients in whom the benefits are predicted to outweigh the risks.

The mainstay of efficacy prediction for PD-(L)1 inhibitors is the quantification of tumor PD-L1 expression, for which several FDA-approved commercial assays exist ${ }^{6}$. Present guidelines $\left(\mathrm{ASCO}\right.$ and $\mathrm{ESMO}^{7}$ ) recommend first-line monotherapy with PD-(L)1 inhibitors for advanced NSCLC only when the PD-L1 tumor proportion scores (TPS) is at least $50 \%$, that is $\geq 50 \%$ of viable tumor cells are positive for membrane staining of PD-L1. However, the necessity to biopsy and process tissue, spatial tumor heterogeneity, the use of different assay systems (three are FDA-approved) and different cut-offs, limit the accuracy and pose limitations to the consistency of this companion diagnostic approach ${ }^{1,8,9}$. Furthermore, because of a lack of alternative predictive biomarkers, potential responder populations outside the recommended PD-L1 TPS bracket are excluded from first-line PD-(L)1 inhibitor monotherapy. Accurately identifying responders independently of PD-L1 could expand the eligible population for immunomonotherapies, which would reduce the burden of chemotherapy toxicity for lung cancer patients.

Multiple lines of evidence suggest that information held in peripheral blood may be reflective of the immune response within the tumor microenvironment (TME). Associations have been found between immunotherapy response and peripheral blood counts ${ }^{10}$, peripherally expanded T-cell clones ${ }^{11}$, and monocyte subpopulations ${ }^{12}$. Based on this abundance of peripheral signal, we sought to define an immunotherapy response prediction signature from 
medRxiv preprint doi: https://doi.org/10.1101/2021.10.31.21265722; this version posted November 1,2021 . The copyright holder for this preprint (which was not certified by peer review) is the author/funder, who has granted medRxiv a license to display the preprint in All rights reserved. No reuse allowed without permission.

1 whole blood microRNA (miRNA) expression profiles. miRNAs are $\sim 22$-nt short RNA molecules

2 that regulate target messenger RNAs (mRNAs) through Watson-Crick base-pairing to miRNA response elements (MREs) frequently embedded in the 3'-untranslated region (UTR) of target genes ${ }^{13}$. This positions miRNAs as sophisticated regulators of gene expression, which can reflect immune status and activity ${ }^{14}$. To ensure a simple, robust, and reproducible platform, the IVD-certified PAXgene Blood RNA System (PAXgene) was used for the collection, lysis, and subsequent RNA stabilisation of whole blood samples to enable "pipetting- and cell sorting-free" sample collection in the clinic $^{15}$. Analytical processes, including RNA extraction, library preparation, and next generation sequencing (NGS) were optimised to measure a whole blood, immune enriched, small RNA expression profile. Using several cohorts of stage IV NSCLC patients, we developed a model using miRNA expression profiles to predict overall survival (OS) following monotherapy with either pembrolizumab or nivolumab. We uncovered a myeloid enriched 5 miRNA-signature (miRisk score) which outperforms PD-L1 TPS and generalizes to an independent validation cohort. The miRisk score is specifically predictive of response to immunotherapy rather than a more general prognostic marker thus offering the prospect of a blood-based companion diagnostic.

Results

\section{Clinical patient characteristics}

The 96 patients in the training cohort of stage IV NSCLC patients who received anti-PD-1 monotherapy comprised $77 \%(n=74)$ pembrolizumab- and $23 \%(n=22)$ nivolumab-treated patients; $58 \%$ adenocarcinomas $(n=56), 28 \%$ squamous cell carcinomas $(n=27)$, and $14 \%$ other NSCLCs ( $\mathrm{n}=13$, including NSCLC, NOS and large-cell neuroendocrine lung carcinomas); $62.5 \%$ males; $91.7 \%$ former or current smokers (Table 1 ). Immunotherapy was administered in the first line to $49 \%$, in the second line to $48 \%$, and beyond the second-line to only $3 \%$ of the patients (Table 1 ). $71 \%$ had PD-L1 TPS $\geq 50 \%, 21 \% 1-49 \%$, and $8 \%<1 \%$, while ECOG performance status (PS) at the time of immunotherapy start was 0 in $37 \%, 1$ in $58 \%$, and 2 in $5 \%$ of cases. The clinical characteristics of the independent validation cohort are similar and shown in Table 1. The independent control cohort consisted of 139 stage IV NSCLC patients treated with combined chemoimmunotherapy but who otherwise display broadly similar clincopathological features (Table 1). 
medRxiv preprint doi: https://doi.org/10.1101/2021.10.31.21265722; this version posted November 1,2021 . The copyright holder for this preprint (which was not certified by peer review) is the author/funder, who has granted medRxiv a license to display the preprint in perpetuity.

All rights reserved. No reuse allowed without permission.

2 Whole blood miRNA profiling is limited by the presence of a small number of highly abundant erythroid miRNAs. On average $50 \%$ of reads in a PAXgene library map to either miR-486-5p, miR-451a, or miR-16-5p (Fig. 1a). This limits the sequencing bandwidth available for the detection and accurate quantification of other RNA species. Analogous to the blocking of ribosomal RNA or haemoglobin mRNA during the preparation of mRNA sequencing libraries, we generated an immune cell enriched (red blood cell (RBC) depleted) small RNA library by blocking the incorporation of the 2 most highly abundant erythroid miRNAs (miR-486-5p and miR-451a) during the construction of our sequencing libraries (Fig. 1b). In addition, we blocked the incorporation of miR-16-5p, which we have observed to be overrepresented in the final libraries as a consequence of potential mimicking of the native substrate of T4 RNA ligase 1 (Supplementary Fig. 1h) ${ }^{16,17}$. Blocking was performed with custom oligonucleotides that were designed to target the consensus sequence of the chosen highly abundant miRNAs and their isomiRs (Supplementary Fig. 1d-f). The specificity and efficiency of miRNA blocking was assessed by the paired sequencing of PAXgene samples using either an unblocked or blocked library preparation. The proportion of reads mapping to the three intended targets of blocking is efficiently reduced by $99.96 \%$ in blocked compared to unblocked libraries (Fig. 1c). The liberated sequencing bandwidth resulted in an increase of blocked reads per million (RPM) values, enabling a more accurate quantification of less abundant but potentially more informative immune cell derived miRNAs at a given sequencing depth (Fig. 1d). The global miRNA expression profile was minimally affected as revealed by the high correlation coefficient (Fig. 1d, $r=0.99$ ).

Building a miRNA-based risk model for OS under PD-1 inhibitor monotherapy

miRNA expression from patients in the Training Cohort (96 patients) were used to develop a model to predict OS of stage IV NSCLC patients receiving single agent immunotherapy of either pembrolizumab or nivolumab. A computational pipeline based on that described by Shukla et al., was created to perform initial filtering of features based on Cox univariable association with survival (miRNA shortlist, Supplementary Table 1), before a further stepwise multivariable Cox regression was used to create a multiple miRNA signature ${ }^{18}$. To choose a small subset of features that would be amenable to alternative low throughput quantification platforms (eg. qRT-PCR) and avoid model overfitting, we performed a cross-validated grid search during training (stepwise selection of 3-10 features) that identified multivariable models containing five features as optimal. Finally, a Cox proportional hazards model was fit to the entire training dataset using five miRNA features ideintified through forward sequential feature selection to generate the following linear predictor risk score: $m i R i s k=(\log (\mathrm{miR}-2115-3 p$ RPM 
medRxiv preprint doi: https://doi.org/10.1101/2021.10.31.21265722; this version posted November 1,2021 . The copyright holder for this preprint (which was not certified by peer review) is the author/funder, who has granted medRxiv a license to display the preprint in All rights reserved. No reuse allowed without permission.

+ 1) $\times 1.870)+(\log (\operatorname{miR}-218-5 p \mathrm{RPM}+1) \times 0.907)+(\log (\operatorname{miR}-224-5 p \mathrm{RPM}+1) \times 0.495)+$ $(\log (\mathrm{miR}-4676-3 p \mathrm{RPM}+1) \times 1.309)+(\log (\mathrm{miR}-6503-5 p \mathrm{RPM}+1) \times 1.159)$

miRisk scores were calculated for all 96 patients in the training cohort (Table 1) and patients were separated into low/high risk groups based on the median risk score threshold (5.61). Patients in the low-risk group survive for significantly longer than those in the high-risk group (hazard ratio (HR) 3.98, 95\% confidence interval (Cl) 2.29-4.54; $P<0.01$ ) (Fig. 2a). To quantify the generalizability of the model on a sample of independent patients, we applied the miRisk score to 99 patients in the validation cohort (Table 1), and stratified into low/high risk groups using the same cut-off (5.61). Patients in the low-risk group survived for significantly longer than those in the high-risk group (HR 2.40, 95\% Cl 1.37-4.19; $P<0.01$ ) (Fig. 2b). The discriminative ability of the miRisk score was assessed using time dependent receiver operating characteristic (ROC) curve analysis to summarize OS at 6 months (Fig. $2 \mathrm{~g}-\mathrm{i}$ ). The areas under the time dependent ROC curve (AUC) were 0.87 (95\% Cl 0.78-0.95) and 0.71 $(95 \% \mathrm{Cl} 0.58-0.82)$ in the training and validation cohorts respectively, further supporting the relationship between the miRisk score and OS in stage IV NSCLC patients receiving immunotherapy at the clinically relevant timepoint of 6 months.

To explore whether non-linear models could reproduce and/or increase predictive performance, we trained and evaluated a random forest classifier on our dataset ${ }^{19}$. A random forest was fit to all miRNA expression features within the training cohort, without any prior feature selection, and the resultant median risk score was used to stratify patients into low/high risk groups. We observed significant differences in OS between the risk groups in both the training and independent validation cohorts (Supplementary Fig. 2a and 2b, respectively; HR 4.94, 95\% Cl 2.82-8.66; $\mathrm{P}<0.01$; and HR 1.84, 95\% Cl 0.98-3.44; $P=0.03$, respectively). Finally, permutation-based feature importance was used to identify the most informative miRNA features used by the random forest classifier. We observed $3 / 5$ of the miRisk miRNAs, which were identified in the previously described approach, were amongst the most important features used by the random forest classifier including miR-2115-3p, the feature from the miRisk model with the greatest weighting (Supplementary Fig. 2c).

The NGS measured expression levels of four of the five miRNAs that contribute to the miRisk score are observed to be significantly increased in high-risk patients (Fig. 3a-e). Only miR218-5p is expressed at similar levels within the high- and low-risk groups (Fig. 3b). To technically validate our findings using an orthogonal method, we remeasured the miRNA expression profiles of 95 patients (one patient had insufficient RNA available) from the training 
medRxiv preprint doi: https://doi.org/10.1101/2021.10.31.21265722; this version posted November 1, 2021. The copyright holder for this preprint (which was not certified by peer review) is the author/funder, who has granted medRxiv a license to display the preprint in All rights reserved. No reuse allowed without permission.

1 cohort using qRT-PCR. This analysis recapitulated the NGS results for all five miRNAs with

2 identical direction of change and similar degrees of significance (Fig. 3f-j).

3

4

Together, we trained two entirely different models on our dataset and observed convergence on a subset of informative miRNA features. We technically validated the quantification of features by showing consistency between measurements from both NGS and qRT-PCR. Given the greater hazard ratio between risk groups predicted by the Cox based miRisk score compared to random forests, and its ease of interpretability, the miRisk score was chosen for further investigation.

miRisk score is predictive for PD-1 inhibitor monotherapy, not prognostic

In order to discern the potential predictive vs. prognostic importance of the miRisk score, we explored the model performance in a further distinct control cohort treated with combined chemoimmunotherapy (Table 1). We observed no significant difference in survival between those in the low-risk versus high-risk groups (HR 1.36, 95\% Cl 0.72-2.57; $P=0.37$ ) (Fig. 2c). Similarly, we observed no significant prediction of 6 month survival with the miRisk score in the control cohort using the time dependent ROC analysis (Fig. 2i).

\section{Evaluating the miRisk score in a clinical context}

To explore the association between the miRisk score and other clinical covariates with respect to OS, both univariable and multivariable Cox regression were performed within the validation cohort (Table 2). In addition to the miRisk score, we included clinicopathological covariates of relevance to immunotherapy response in these models. Based on the univariable analysis, we observed significant associations between OS and ECOG (HR 2.82, 95\% Cl 1.47-5.41; $P<$ 0.01), absolute neutrophil count (ANC) (HR 1.98, 95\% Cl 1.08-3.62; $P=0.03$ ), absolute lymphocyte count (ALC) (HR 0.57, 95\% Cl 0.32-0.99; $P<0.05)$ and the miRisk score (HR $2.47,95 \% \mathrm{Cl} 1.36-4.48 ; P<0.01)$. The beneficial effect from both low ANC and high ALC is consistent with a previously published predictive signature derived from peripheral blood counts ${ }^{10}$. We observed a trend towards increased risk with low PD-L1 TPS in the validation cohort; however, this does not reach significance (HR 1.78, 95\% Cl 0.97-3.28; $P=0.06$ ) (Table 2).

Based on the multivariable analysis, the association between blood counts and OS is attenuated when controlling for all other covariates. Both ECOG (HR 4.61, 95\% Cl 2.21-9.59; 
medRxiv preprint doi: https://doi.org/10.1101/2021.10.31.21265722; this version posted November 1,2021 . The copyright holder for this preprint (which was not certified by peer review) is the author/funder, who has granted medRxiv a license to display the preprint in perpetuity.

All rights reserved. No reuse allowed without permission.

$1 \quad P<0.01)$ and the miRisk score (HR 2.40,95\% Cl 1.12-5.14; $P=0.02)$ remained significantly associated with OS after controlling for other clinicopathological covariates (Table 2).

miRisk score outperforms PD-L1 histology as a predictive biomarker in advanced NSCLC

To test the performance of the established gold standard biomarker in our clinical samples, we stratified patients within the training, validation and control cohorts based on PD-L1 TPS (>50\% vs. $\leq 50 \%$ ). There is a trend towards longer OS in the high PD-L1 patients, but this does not reach significance in any cohort (Fig. 2d-f). To quantify the increase in predictive performance of the miRisk score over PD-L1 TPS, we calculated the difference in time dependent ROC AUC at 6 months using either the miRisk score or PD-L1 TPS over 1000 bootstrapped datasets. ROC AUCs increased by $0.36(95 \% \mathrm{Cl} 0.22-0.50)$ and $0.18(95 \% \mathrm{Cl}$ 0.01-0.35) in the training and validation datasets respectively, when classified by miRisk score compared to PD-L1 TPS (Fig. 2g-h). To explore any potential additive performance, we retrained a Cox model using PD-L1 TPS in addition to the five previously identified signature miRNAs (miRisk+PD-L1). Using this model, we observed a difference in time dependent ROC AUC of $-0.01(95 \% \mathrm{Cl}-0.04-0.02)$ and $0.01(95 \% \mathrm{Cl}-0.04-0.05)$ in the training and validation cohorts respectively, demonstrating no significant incremental improvement in the miRisk + PD-L1 score performance compared to the miRisk score (Fig. 2g-h).

Together, this provides evidence of significantly superior performance of the blood-based miRisk score compared to tissue-based PD-L1 TPS when predicting OS at 6 months. These results corroborate the limitations of PD-L1 TPS as an immunotherapy efficacy predictor and are consistent with a recent meta-analysis that found PD-L1 TPS to be predictive of immunotherapy response in only approximately $30 \%$ of patients across a range of tumour types ${ }^{20}$.

Predictive miRNAs are of myeloid origin

To deconstruct the contribution of distinct blood cell types to the mixed-cell PAXgene whole blood profile, we sequenced small RNAs of 10 purified cell populations sorted to high purity (Supplementary Table 2) from blood donated by 12 healthy volunteers between 50 and 60 years old (Supplementary Fig. 3). This enabled the creation of a blood cell type miRNA expression atlas and an exploration into the cell of origin of the 5 miRisk miRNAs. To integrate the blood cell type miRNA expression atlas with PAXgene whole blood miRNA expression profiles, a custom scaling factor was applied to the individual miRNA expression data, based on cell type abundance and intracellular RNA content (see Methods for calculation and 
medRxiv preprint doi: https://doi.org/10.1101/2021.10.31.21265722; this version posted November 1,2021 . The copyright holder for this preprint (which was not certified by peer review) is the author/funder, who has granted medRxiv a license to display the preprint in perpetuity.

All rights reserved. No reuse allowed without permission.

1 Supplementary Table 3). This enabled a deconvolved picture of PAXgene miRNA expression

2 based on the relative contributions of the dominant peripheral blood cell types (Fig. 4a). The

3 dominance of RBCs in PAXgene small RNA preparations is apparent, as observed by 259 whole blood miRNAs predominantly originating from RBCs. The next most dominant cell type in terms of contribution to the PAXgene profile are platelets, which are the major source of a further 109 miRNAs. miRNAs that show immune cell restricted expression are in the minority (Fig. 4a).

\section{Pathway analysis of predictive miRNAs and interaction with PD-1/PD-L1 signalling}

To further characterize the mechanistic link between the miRisk miRNAs and immunotherapy response, we performed bioinformatic target prediction and pathway analysis. Employing the TargetScan algorithm ${ }^{21}$, we identified predicted target genes for both the 44 miRNAs significantly associated with OS (Supplementary Table 1), and the 5 miRNAs that contribute to the miRisk score. These gene sets were then used as inputs for pathway enrichment analysis using the KEGG database ${ }^{22}$. PD-L1 pathway genes are significantly enriched amongst targets of the 44 miRNA shortlist (1.22-fold enrichment, adjusted $\left.P=4.8 \times 10^{-5}\right)$ and display a trend towards enrichment within the targets of the miRisk miRNAs (1.22-fold enrichment, adjusted $P=0.05$ ) (Supplementary Table 4, Supplementary Fig. 5). Interestingly, this analysis revealed predicted direct interactions between PD-L1 (CD274) itself and the miRisk miRNAs miR-2115-3p, miR-4676-3p and miR-6503-5p (Supplementary Fig. 6a). Furthermore, the MAPK signalling pathway was identified as a highly enriched pathway amongst target genes of the miRisk miRNAs (1.21-fold enrichment, adjusted $p$-value $=1.6 \times 10^{-}$ 
medRxiv preprint doi: https://doi.org/10.1101/2021.10.31.21265722; this version posted November 1,2021 . The copyright holder for this preprint (which was not certified by peer review) is the author/funder, who has granted medRxiv a license to display the preprint in perpetuity.

All rights reserved. No reuse allowed without permission.

$\left.{ }^{3}\right)$ (Supplementary Fig. 5b). This further suggests a potential functional link as the PD-L1/PD1 pathway is upregulated by upstream signalling through the MAPK pathway ${ }^{23}$.

\section{Discussion}

Response to immunotherapy is likely governed by the complex interplay between tumor and immune dependent factors, inherently limiting response prediction based on single biomarkers (e.g. PD-L1) or unilateral tumor-derived parameters (e.g. plasma tumor mutational burden (pTMB)). Instead, integrating multiple omics covariates may offer a better reflection of this complexity and thus a more accurate evaluation of risk and benefit ${ }^{24-27}$. Here we describe the discovery, validation and mechanistic insight into a 5 miRNA risk score (miRisk) measured in peripheral blood that predicts OS of stage IV NSCLC patients receiving PD-1 inhibitor monotherapy, and which performs better than the current standard of care, tissue PD-L1 TPS. We anticipate that as the evidence-based algorithms of clinical practice continue to evolve, such companion or complementary diagnostics will be vital to further refine patient management and deliver on the promise of personalized and precision medicine.

In this study we used peripheral blood miRNA profiles as a proxy for phenotypic inference into the tumor immune microenvironment (TME) and its susceptibility to immunotherapy. Our miRisk score likely captures and integrates information from multiple peripheral immune sources, reflective of the systemic immune status. Deconvolution of the PAXgene small RNA profiles into individual cell types revealed a remarkable myeloid specific expression pattern, largely originating from monocytes and neutrophils (miR-2115-3p, miR-4676-3p, miR-6503$5 p$ ), and platelets (miR-224-5p). Only miR-218-3p showed a heterogeneous pattern of expression (Fig.4c). Our findings are consistent with the growing evidence that peripheral biomarkers are predictive of response to immunotherapy ${ }^{10-12,28,29}$. Myeloid cells, particularly monocytes but also neutrophils, have become increasingly recognized key players configuring the TME ${ }^{30-32}$. Myeloid Derived Suppressor Cells (MDSCs) have been shown to play critical roles in establishing an immunosuppressive TME and their subsequent response to immune checkpoint blockade ${ }^{33,34}$. Furthermore, platelets and more specifically tumor educated platelets have been described to undergo transcriptional changes upon transit through the TME and maintain memory of these events when they return to the periphery ${ }^{35-37}$. Given this body of evidence, and our observed correlation between miRisk miRNAs and peripheral blood cell counts (particularly miR-2115-3p and neutrophils), it is likely that some of the miRisk performance is derived from an indirect measure of blood count. However, the demonstration of the miRisk score as an independent significant predictor of OS in multivariable Cox analysis 
medRxiv preprint doi: https://doi.org/10.1101/2021.10.31.21265722; this version posted November 1,2021 . The copyright holder for this preprint (which was not certified by peer review) is the author/funder, who has granted medRxiv a license to display the preprint in

All rights reserved. No reuse allowed without permission.

1 (Table 2) is evidence that it captures additional information of relevance to the efficacy of 2 immunotherapies.

4 Our work also provides insight into the mechanistic validity of the miRisk score. We have demonstrated the specificity of the miRisk score to prediction of OS in stage IV NSCLC patients treated with immunomonotherapy, but not combined chemotherapy and immunotherapy (Fig. 2). This is consistent with multiple reports of the blunting of predictive ability for several other promising immunologic biomarkers, like the PD-L1, TMB and ALI, when chemotherapy is added to immunotherapy ${ }^{38-40}$. Furthermore, we have used bioinformatic analyses to reveal an overrepresentation of miRisk miRNA targets within the PD1/PD-L1 signaling pathway, including multiple predicted direct interactions with PD-L1 itself. Together we propose a possible mechanism whereby lower expression of the miRisk miRNAs in responder patients may correspond to a derepression of signaling through the PD-1/PD-L1 pathway in peripheral immune cells which is maintained upon their migration into the TME (Supplementary Fig. 6b). This could establish a TME in which immunosuppression depends more heavily on the PD-1/PD-L1 axis, and therefore could also be particularly susceptible to pharmacological inhibition of this pathway.

A reliable blood-based companion diagnostic biomarker for immunotherapy in NSCLC has the potential to dramatically improve patient care and outcomes. Some examples of potential clinical applications include the selection of suitable patients with PD-L1 $<50 \%$ for PD-1 inhibitor monotherapy, selection of suitable PD-L1-high patients for immunomonotherapy vs. chemoimmunotherapy, selection of IO-pretreated patients in later lines for re-exposition to PD(L)1 inhibitor therapy, and the decision of whether to continue PD-(L)1 inhibitor therapy beyond 2 years in patients with ongoing responses. In addition, due to the mechanistic underpinnings, serial miRisk measurements might provide a practical, non-invasive aid for translational studies aiming to characterize the temporal dynamics and immunobiology of tumor escape from immunotherapy in NSCLC, for example by helping identify suitable time-points for tissue rebiopsies under immunotherapy.

Specific methodological strengths of our study are the custom blocking of highly abundant erythroid miRNAs, which facilitated study of less frequent, but immunologically more relevant miRNA species; the comprehensive bioinformatic evaluation including consistency of the results from two independent analyses based on Cox and random forest models; as well as the utilization of well-sized independent patient cohorts treated in two German lung cancer centers of excellence, with deep clinical annotation and long standing expertise in prospective 
medRxiv preprint doi: https://doi.org/10.1101/2021.10.31.21265722; this version posted November 1,2021 . The copyright holder for this preprint (which was not certified by peer review) is the author/funder, who has granted medRxiv a license to display the preprint in All rights reserved. No reuse allowed without permission.

date, the miRisk score as a predictor of patient OS on immunotherapy has only been validated in a single independent patient cohort. We are currently recruiting additional NSCLC patients to further assess the performance of the model. Furthermore, although we propose a systemic mechanism which could in principle be independent of primary tumor site, we have not yet assessed the miRisk score in cancers other than NSCLC. We are currently collecting additional patients suffering from other cancer types to evaluate whether miRisk is universally applicable. Lastly, the hypothetical mechanism behind miRisk is largely based on bioinformatic analyses at present. Future work will be needed to demonstrate the interaction between miRisk miRNAs and PD-L1 expression directly, both in circulating blood cells and the TME.

In summary our findings demonstrate the potential utility of peripheral blood-based miRNAs as markers of response prediction to immunotherapy in advanced NSCLC. This work may improve our understanding of tumor immunobiology and, if validated, offers several important opportunities to improve management and outcome of patients with advanced NSCLC and possibly also other tumors.

\section{Methods}

\section{Patient enrolment}

This study was approved by the Heidelberg University (S-296/2016, S-089/2019) and Grosshansdorf Hospital ethics committee (AZ 12-238) and involved patients with advanced NSCLC treated with immunotherapy alone or immunotherapy in combination with chemotherapy, for which blood samples were available. These were collected prospectively as published ${ }^{41}$ and provided by the Lungenbiobank Heidelberg and Biobank Nord for the present analysis according to the pertinent regulations. Initially, a training cohort of 96 patients treated with PD-1 inhibitor monotherapy was assembled from Heidelberg, followed by an independent validation cohort of 99 additional patients who received PD-1 monotherapy in either Heidelberg $(n=84)$ or Großhansdorf $(n=15)$, as well as an independent control cohort of 139 patients who received chemoimmunotherapy in Heidelberg (Table 1). Diagnosis of NSCLC was performed in the Institute of Pathology Heidelberg and Borstel using tissue specimens according to the criteria of the current WHO classification (2015) for lung cancer, as described previously ${ }^{42,43}$. Clinical data and laboratory results were collected by a systematic review of patient records, as described ${ }^{41}$. The following clinical data were extracted: demographic, baseline clinical and tumor characteristics, including ECOG PS, smoking status, PD-L1 TPS, laboratory results, systemic and local anticancer treatments, date of progression, date of the last follow-up, and date of death. OS was calculated from start of immunotherapy to the time of last follow-up or death. For PD-L1 TPS assessment, the clones SP263 
medRxiv preprint doi: https://doi.org/10.1101/2021.10.31.21265722; this version posted November 1,2021 . The copyright holder for this preprint (which was not certified by peer review) is the author/funder, who has granted medRxiv a license to display the preprint in perpetuity.

All rights reserved. No reuse allowed without permission.

1 (Ventana/Roche, Mannheim, Germany) and E1L3N (Cell Signaling Technology Europe B.V.)

2 were used in Heidelberg and Mannheim, respectively, and values trichotomized as < 1, 1-49, and $\geq 50 \%$, reflecting the relevant thresholds in current treatment guidelines ${ }^{44}$.

PAXgene collection and processing

PAXgene (PreAnalytiX, Hombrechtikon, Switzerland) blood samples were acquired as per manufacturer instructions, inverted immediately $10 \mathrm{x}$ and frozen at $-20^{\circ} \mathrm{C}$ within 2 hours. For long-term storage the tubes were transferred to $-80^{\circ} \mathrm{C}$. Training Cohort. The PAXgene tubes were thawed overnight and extracted using the PAXgene Blood miRNA Kit (Qiagen, Venlo, Netherlands) as per manufacturer instructions. Eluates of $80 \mu \mathrm{l}$ in RNase-free water were stored in $-80^{\circ} \mathrm{C}$. Validation and Control Cohorts. For the 223 Heidelberg patients, PAXgene tubes were thawed overnight, and RNA was extracted using PAXgene Blood RNA Kit (Qiagen, Venlo, Netherlands). The flow-through of the first column (RNA shredder column) was saved and stored in $-20^{\circ} \mathrm{C}$ and used for further extraction of RNAs $<200$ nts of length. For this purpose, the alcohol content of the sample was brought to $50 \%(\mathrm{w} / \mathrm{v})$ with isopropanol and the samples were processed further using PAXgene Blood miRNA Kit, starting from the RNA column step. The RNA was eluted in $40 \mu \mathrm{l}$ RNase-free water and stored at $-80^{\circ} \mathrm{C}$. The RNA from PAXgene samples of the 15 Grosshansdorf patients was extracted using the QIAsymphony PAXgene Blood RNA Kit on the QIAsymphony SP liquid handling station (Qiagen, Venlo, Netherlands). The elution was performed at $72^{\circ} \mathrm{C}$ for $10 \mathrm{~min}$ in $200 \mu \mathrm{l}$ of elution buffer. The RNA was aliquoted and stored at $-80^{\circ} \mathrm{C}$.

\section{Small RNA-seq}

$100 \mathrm{ng}$ of total RNA, or $5 \mu \mathrm{l}$ of total RNA (for samples with concentration lower than $20 \mathrm{ng} / \mathrm{\mu l}$ ) were used for QIAseq ${ }^{\circledR}$ miRNA Library Kit (Qiagen, Venlo, Netherlands). To block highly abundant miRNAs (miR-16-5p, miR-486-5p, miR-451a), custom blocking reagent FastSelect (Qiagen, Venlo, Netherlands) was used and added before the RT step. cDNA was amplified using primers (Supplementary Table 5) allowing unique dual indexing of the libraries and PCR products were cleaned-up using Mag-Bind TotalPure NGS beads (Omega Bio-Tek, Norcross, USA). PCR products following 18 cycles of amplification were assessed for size and uniformity using the Quantitative DNA kit on Fragment Analyzer (Agilent, Santa Clara, USA). The concentration of the PCR products was determined by Quant-iT dsDNA Assay-Kit (ThermoFisher Scientific, Waltham, USA), and equimolar library pools with up to 96 samples were prepared and sequenced on NextSeq 500 (Illumina, San Diego, California) with a 2.7 pM final pooled library concentration. A custom index 2 sequencing primer with the sequence 
medRxiv preprint doi: https://doi.org/10.1101/2021.10.31.21265722; this version posted November 1,2021 . The copyright holder for this preprint (which was not certified by peer review) is the author/funder, who has granted medRxiv a license to display the preprint in perpetuity.

All rights reserved. No reuse allowed without permission.

\section{Blocking design and efficiency evaluation}

We designed blocking oligonucleotides for the three most abundant miRNAs (hsa-miR-4865p, hsa-miR-16-5p, hsa-miR-451a) within PAXgene whole blood libraries to target the consensus sequence defined from the alignment of the 20 most prevalent respective isomiR sequences (see Supplementary Fig. 1). Based on these consensus sequences, customized QIAseq® FastSelect RNA Removal Kits were obtained and deployed immediately prior to the reverse transcription step of library preparation (Fig. 1b). To evaluate the blocking efficiency, small RNA-Seq of the 96 PAXgene samples of the training cohort was performed using either an unblocked or blocked library preparation protocol (see section below). For illustration, the proportion of each miRNA in the total read counts was calculated for each sample. Additionally, the log2-transformed reads per million (RPM) value in each sample was calculated for the 1517 miRNAs that were detected in both libraries. The mean values of log2transformed RPM values per miRNA in the unblocked and blocked samples were used for plotting as well as calculating the Pearson coefficient for unblocked and blocked samples.

\section{Statistical analysis}

Non-penalized, univariable and multiviable Cox models for survival regression were fit in Python using the packages scikit-survival (version 0.15.1) ${ }^{19}$ and Lifelines (version 0.26.0 ${ }^{45}$ using the CoxPHSurvivalAnalysis and CoxPHFitter classes respectively with defult parameter settings. In order to overcome the $\mathrm{p}$ >> n problem while modelling survival in high dimensional data, Witten and Tibshirani have proposed a number of methods including discrete feature selection using univariable and stepwise selection ${ }^{46}$. These have been implemented with the package scikit-learn (version 0.24.2) (7) $^{4}$ and the SelectFpr (selecting miRNA features to which a Cox proportional hazards model could be fit with $P<0.05$ ) and SequentialFeatureSelector (sequentially adding single miRNA features to a multivariable Cox proportional hazards model and assessing based on minimising the log-rank test $P$ value between low/high risk crossvalidated predictions) classes. Scikit-learn pipelines were used to couple the feature selection and training steps to create survival models and perform inference on new data.

Random survival forests from the scikit-survival package were used to train forests using the parameter settings: n_estimators $=1000$, min_samples_split $=10$, min_samples_leaf $=15$, max_features="sqrt". Feature importance was assessed using the permutation based method from the package ELI5 (version 0.11 .0 ) by estimating the reduction in model concordance index when removing the association between survival and each feature in turn (through random shuffling).

Patients were stratified into high/low risk groups by the median risk score in the training data, based on the cutpoint definition of similar previously described prognostic gene expression signatures ${ }^{48-50}$. Prognostic performance of the miRisk score was assessed in a multivariable 
medRxiv preprint doi: https://doi.org/10.1101/2021.10.31.21265722; this version posted November 1,2021 . The copyright holder for this preprint (which was not certified by peer review) is the author/funder, who has granted medRxiv a license to display the preprint in perpetuity.

All rights reserved. No reuse allowed without permission.

1 Cox proportional hazards model with additional clinicopathological covariates (PD-L1, ECOG, 2 gender, age, therapy line, substance, histology, smoking status, ANC, ALC). The survival 3 function was estimated using the Kaplan-Meier method, and groups were compared with the 4 log-rank test.

5 Time dependent ROC curve analysis was performed in R with the package timeROC and bootsrapping was performed to quantify differences in AUC between models (e.g., miRisk versus miRisk + PD-L1).

8

qRT-PCR

Catalogue and custom miRCury LNA miRNA PCR assays were ordered from Qiagen (Venlo, Netherlands) for biomarker miRNAs and housekeeping miRNAs (Supplementary Table 6). $500 \mathrm{ng}$ RNA was used for CDNA synthesis, or when the concentration was insufficient, up to $6.5 \mu$ of RNA volume was used. cDNA was then diluted 1:80,10 $\mu$ total volume reaction was set up according to manufacturer's instructions, and cycled according to the following protocol: 2 min at $95^{\circ} \mathrm{C}, 40 \times 10$ s at $95^{\circ} \mathrm{C} 60$ s at $56^{\circ} \mathrm{C}$ in $\mathrm{AB}$ Flex 6 cycler in 384-well format. A melt curve analysis was performed at $60-95^{\circ} \mathrm{C}$. The $C_{t}$ values were determined and exported using QuantStudio RealTime PCR Software version 1.3. For the training cohort of 95 patients, the $\mathrm{C}_{\mathrm{t}}$ values of the five miRisk miRNAs were determined in triplicates. $\Delta \mathrm{C}_{\mathrm{t}}$ values were calculated by subtracting the mean of the $C_{t}$ values of "housekeeping" miRNAs that were previously defined by NGS on the basis of low variance. Based on these $\Delta C_{t}$ values the fold change $\left(2^{\Delta \Delta C t}\right)$ and t-test between samples from patients with low or high risk according to the miRisk score was calculated per signature miRNA.

\section{Purification of blood cells}

Cell sorting was performed immediately after donation of human whole blood. An overview is provided in Supplementary Fig. 5. Whole blood was collected in S-Monovette ${ }^{\circledR}$ EDTA K3 tubes (Sarstedt AG \& Co. KG, Nümbrecht, Germany). To isolate CD4+ T-cells, CD8+ T-cells, monocytes, and B-cells directly from whole blood, $350 \mu \mathrm{L}$ MicroBeads of the corresponding kit (see Supplementary Table 7) were added separately to $7 \mathrm{~mL}$ EDTA K3 blood. After incubating for $15 \mathrm{~min}$ at $4^{\circ} \mathrm{C}$, cell suspensions were washed by adding isolation buffer to the cell suspension, performing a centrifugation step of $5 \mathrm{~min}$ at $400 \mathrm{xg}$ and $4^{\circ} \mathrm{C}$, and discarding the supernatant. Next, the resulting pellets were resuspended in $1 \mathrm{~mL}$ isolation buffer. Lastly, a positive selection of the magnetic labelled cells was performed with the autoMACS $\circledast$ Pro Separator (Miltenyi Biotec GmbH, Bergisch Gladbach, Germany).

For the isolation of neutrophils and NK cells, the corresponding MACSxpress ${ }^{\circledR}$ Whole Blood Isolation reagent (Supplementary Table 7) was added in a ratio of 1:2 to the whole blood. Next, tubes were rotated in a MACSmix ${ }^{\text {TM }}$ Tube Rotator (Miltenyi Biotec $\mathrm{GmbH}$, Bergisch 
medRxiv preprint doi: https://doi.org/10.1101/2021.10.31.21265722; this version posted November 1,2021 . The copyright holder for this preprint (which was not certified by peer review) is the author/funder, who has granted medRxiv a license to display the preprint in perpetuity.

All rights reserved. No reuse allowed without permission.

1 Gladbach, Germany) for 5 min at room temperature. After 15 min on a MACSxpress Separator (Miltenyi Biotec $\mathrm{GmbH}$, Bergisch Gladbach, Germany) the supernatant containing the cell populations was collected. To further purify neutrophils and NK cells, a lysis of erythrocytes was performed by adding $20 \mathrm{~mL} 0.2 \% \mathrm{NaCl}$ solution (Merck KGaA, Darmstadt, Germany) for $20 \mathrm{~s}$ and $20 \mathrm{~mL} 1.6 \% \mathrm{NaCl}$ solution thereafter and the cell pellet was saved after centrifugation for $5 \mathrm{~min}$ at $300 \times g$ and $4{ }^{\circ} \mathrm{C}$.

To isolate human thrombocytes, basophils, and eosinophils, whole blood was diluted in a ratio of 2:3 with PBS (Thermo Fisher Scientific, Waltham, USA) and layered over the density gradient medium Histopaque ${ }^{\circledR}-1077$ (Merck KGaA, Darmstadt, Germany) in a ratio of 3:5. After a centrifugation for $20 \mathrm{~min}$ at $600 \times \mathrm{g}$ and RT (no brake), the different layers were isolated immediately.

The uppermost plasma layer was used to isolate platelets. After an additional centrifugation step for $15 \mathrm{~min}$ at $500 \times \mathrm{g}$ and $\mathrm{RT}$, the supernatant was discarded, and the pellet was resuspended in $600 \mu \mathrm{L}$ isolation buffer and $150 \mu \mathrm{L}$ CD61 beads (Supplementary Table 7) were added for positive selection. After an incubation time of $15 \mathrm{~min}$ at $4{ }^{\circ} \mathrm{C}$, the pellet was washed, resuspended in $500 \mu \mathrm{L}$ isolation buffer (0,5\% albumin, 2 mM EDTA in PBS) and thrombocytes isolated with the autoMACS Pro Separator. The interphase ring layer was washed twice with isolation buffer. The isolation of basophils was performed in a two-step procedure with the Diamond Basophil Isolation Kit (Supplementary Table 7). First, the cell pellet was resuspended in $300 \mu \mathrm{L}$ isolation buffer per $10^{8}$ cells, $100 \mu \mathrm{L}$ FcR Blocking Reagent per $10^{8}$ cells, and $100 \mu \mathrm{L}$ Basophil Biotin-Antibody Cocktail per $10^{8}$ cells. After incubating for $10 \mathrm{~min}$ at $4{ }^{\circ} \mathrm{C}, 300 \mu \mathrm{L}$ isolation buffer per $10^{8}$ cells and $200 \mu \mathrm{L}$ Anti-Biotin MicroBeads per $10^{8}$ cells were added. After incubating again for $10 \mathrm{~min}$ at $4{ }^{\circ} \mathrm{C}$, cells were washed, resuspended in $500 \mu \mathrm{L}$ isolation buffer and negative selection was performed with the autoMACS Pro Separator. Afterwards, the enriched fraction was washed, resuspended directly in $100 \mu \mathrm{L} \mathrm{CD123} \mathrm{MicroBeads} \mathrm{and} \mathrm{incubated} \mathrm{for} 15$ min at $4{ }^{\circ} \mathrm{C}$. After washing the resulting cell pellet was resuspended in $500 \mu \mathrm{L}$ isolation buffer and used for positive selection on autoMACS Pro Separator.

The bottom layer was purified by performing several erythrocyte lysis steps. Next, the cell suspension was centrifugated for $5 \mathrm{~min}$ at $300 \times g$ and $4{ }^{\circ} \mathrm{C}$. The pellet was then resuspended in $40 \mu \mathrm{L}$ isolation buffer per $10^{7}$ cells and in $10 \mu \mathrm{L}$ Eosinophil Biotin-Antibody Cocktail per $10^{7}$ cells (Supplementary Table 7). After an incubation time of $10 \mathrm{~min}$ at $4{ }^{\circ} \mathrm{C}, 30 \mu \mathrm{L}$ isolation buffer per $10^{7}$ cells and $20 \mu \mathrm{L}$ Anti-Biotin MicroBeads per $10^{7}$ cells were added to the cell suspension, incubated $15 \mathrm{~min}$ at $4{ }^{\circ} \mathrm{C}$, washed and finally resuspended in $500 \mu \mathrm{L}$ isolation buffer. Eosinophils were isolated with the autoMACS Pro Separator via a negative selection. To separate erythrocytes from human whole blood, $5 \mathrm{~mL}$ whole blood was centrifuged for 10 
medRxiv preprint doi: https://doi.org/10.1101/2021.10.31.21265722; this version posted November 1, 2021. The copyright holder for this preprint (which was not certified by peer review) is the author/funder, who has granted medRxiv a license to display the preprint in All rights reserved. No reuse allowed without permission.

1 stored in $-80^{\circ} \mathrm{C}$. The remaining pellet was resuspended in isolation buffer, filtered with a $40 \mu \mathrm{m}$ cell strainer (Greiner Bio-One $\mathrm{GmbH}$, Frickenhausen, Germany) and diluted in a ratio of 1:3 with isolation buffer. Typically, $3 \times 10^{7}$ erythrocytes were centrifuged for $10 \mathrm{~min}$ at $300 \times \mathrm{g}$ and $4{ }^{\circ} \mathrm{C}$, cell pellet was resuspended in $240 \mu \mathrm{L}$ isolation buffer and $60 \mu \mathrm{L}$ CD235a MicroBeads (Supplementary Table 7) and incubated for $15 \mathrm{~min}$ at $4^{\circ} \mathrm{C}$. After washing, the cell pellet was resuspended in $500 \mu \mathrm{L}$ isolation buffer and used for positive selection on autoMACS Pro

7 Separator.

8 The yield of all purified cell populations was determined, and cell pellets were directly lysed in

9 Qiazol and stored at $-80^{\circ} \mathrm{C}$.

RNA isolation of sorted cell pellets

Cell lysates in Qiazol were thawed on ice and used for RNA isolation using miRNeasy mini kit combined with minElute columns. The RNA was eluted in $18 \mu \mathrm{l}$ of water and stored at $-80^{\circ} \mathrm{C}$.

Clinical differential and epigenetic PCR blood counts of 12 healthy donors

Absolute erythrocyte and platelet counts were obtained from clinical differential blood counts from the University of Heidelberg. Absolute quantifications (cells/ $\mu \mathrm{l})$ of neutrophils, basophils, eosinophils, monocytes, NK cells, CD4+, CD8+, CD19+ cells were performed from EDTA whole blood by Epiontis, Precision for Medicine using epigenetic PCR ${ }^{51}$.

Flow cytometry quality control of sorted cells

Typically, $0.5 \times 10^{5}$ cells were diluted in $2 \mathrm{~mL}$ isolation buffer and centrifuged afterwards for $5 \mathrm{~min}$ at $300 \times \mathrm{g}$ and RT. The cell pellets were resuspended in $100 \mu \mathrm{L}$ isolation buffer, $5 \mu \mathrm{L}$ of Human TruStain FcX ${ }^{\mathrm{TM}}$ (BioLegend; San Diego, USA) was added and pre-incubated for $10 \mathrm{~min}$ at RT. Afterwards, the corresponding antibodies were added (Supplementary Table 8) and incubated for $20 \mathrm{~min}$ at $4{ }^{\circ} \mathrm{C}$ in the dark. Next, $2 \mathrm{~mL}$ isolation buffer was added, centrifuged for $5 \mathrm{~min}$ at $300 \times \mathrm{g}$ and RT and resuspended in $300 \mu \mathrm{L}$ isolation buffer. The FACS measurements were performed on a BD FACSVerse ${ }^{\mathrm{TM}}$ flow cytometer (BD Biosciences, Franklin Lakes, USA) and analysed using BD FACSuite ${ }^{\mathrm{TM}}$ software v1.0.5 (BD Biosciences, Franklin Lakes, USA).

\section{Sorted blood cell NGS data processing}

33 Raw sequences were adapter trimmed and depleted of PCR duplicates based on unique molecular identifiers (UMIs) using a customized $R$ script. To annotate the small RNA sequences the collapsed reads were mapped with Bowtie (version 1.2.3) ${ }^{52}$ to the miRNA hairpin sequences obtained from the miRbase database (version 22$)^{53}$. The counts of 
medRxiv preprint doi: https://doi.org/10.1101/2021.10.31.21265722; this version posted November $1,2021$. The copyright holder for this preprint (which was not certified by peer review) is the author/funder, who has granted medRxiv a license to display the preprint in All rights reserved. No reuse allowed without permission.

canonical miRNA and isomiR sequences were summed up to generate count matrices for the detected miRNAs.

\section{Deconvolution of PAXgene RNA profiles into cellular origins}

We computed the relative contribution of each of the 10 analyzed cell types to the expression of an individual miRNA in whole blood. For this purpose, the RPM values of miRNA $m$ in cell type $c$ and patient $p,\left(x_{m, c, p}\right)$ are multiplied with a scaling factor $\left(\alpha_{c, p}\right)$. This scaling factor accounts for the small RNA content per sorted cell and the number of cells of type $c$ that are

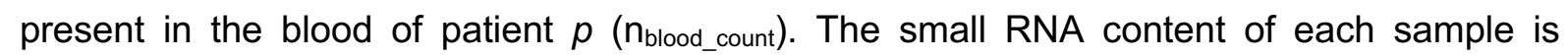
calculated as the product of the small RNA concentration ( $\left.\mathrm{C}_{\mathrm{SRNA}}\right)$ and the elution volume of the sorted cells $\left(V_{\text {elution }}\right)$ divided by the number of sorted cells ( $\left.\mathrm{n}_{\text {sorted_count }}\right)$ :

$$
\alpha_{c, p}=\frac{V_{\text {elution }} * c_{S R N A}}{n_{\text {sorted_count }}} * n_{\text {blood_count }}
$$

The mean of the scaled RPM values of miRNA $m$, per cell type $c$, is aggregated across all patients, $P$ :

$$
\bar{x}_{m, c}=\frac{1}{P} \sum_{p=1}^{P}\left(x_{m, c, p} * \alpha_{c, p}\right)
$$

Finally, the proportion of the scaled mean expression values of each cell type $c$ was calculated per miRNA $m$ :

$$
p_{m, c}=\frac{\bar{x}_{m, c}}{\sum_{c=1}^{C=10} \bar{x}_{m, c}}
$$

These proportions were then used to visualize the cell type distribution of miRNAs of interest and to generate a clustermap of all miRNAs that have read counts $>0$ in whole blood PAXgene small RNA sequencing libraries, using the Python library seaborn (version 3.8$)^{54}$.

\section{Correlation miRNA expression and cell type blood count}

To investigate whether the expression of the 44 survival-associated miRNAs is correlated with the abundance of the cell type they are predominantly expressed in, we calculated Pearson coefficients for RPM values of each miRNA and the blood counts of each cell type based on the training cohort $(n=95)$. The sample with the ID 464_0033 was excluded from this analysis as it had an unusually high monocyte count (5.2 standard deviations above the mean). 
medRxiv preprint doi: https://doi.org/10.1101/2021.10.31.21265722; this version posted November 1, 2021. The copyright holder for this preprint (which was not certified by peer review) is the author/funder, who has granted medRxiv a license to display the preprint in All rights reserved. No reuse allowed without permission.

\section{Target Prediction and Pathway Analysis}

Predicted target mRNAs of the 44 survival-associated miRNAs were defined by the presence of conserved and non-conserved miRNA response elements (MREs) within their 3' UTR using TargetScan (version 7.2,) ${ }^{21}$. KEGG Enrichment Analysis of the predicted targets was performed using the $\mathrm{R}$ package ClusterProfiler (version 3.18.1) ${ }^{55}$.

\section{Data availability}

The data that support the findings of this study are not openly available due to reasons of patient sensitive or potentially identifying data and are available from the corresponding author upon reasonable request.

\section{Code availability}

Data analysis was performed in Python (3.8.8) with the packages scikit-learn (version 0.24.2), scikit-survival (version 0.15.1), and Lifelines (version 0.26.0), and RStudio (Version 1.3.1073) with the package timeROC (version 0.4), and and described in the methods. Raw code will be made available from the corresponding author upon reasonable request.

\section{Acknowledgements}

We thank Stephanie Axenfeld, Urszula Jagos-Ihde, Claudia Genest, Marlen Szewczyk, Milena Schmidt and all other contributing medical personnel at the LungenClinic in Großhansdorf for their outstanding work with patient enrollment and data collection. We also thank Elena Gleim, Elena Neumüller at Hummingbird Diagnostics $\mathrm{GmbH}$ and Helena Schock, PhD for their excellent technical assistance during the study conduct. We thank Mihaela Zavolan and Anastasiya Börsch for discussions of the cell sorting analyses. Finally, we thank all study participants and their families.

\section{Author contribution statement}

T.R., P.C., B.R.S. designed and planned the study. P.C., F.H., K.T., S.H., T.M., S.U., M.A.W., M.E., F.L., H.S., K.F.R., M.R., M.T., organized clinical enrolment and sample and data collection. R.H., J.S., O.P., J.F., J.Sk., D.N., A.D.M., J.C., F.U., Q.W. processed biological material and performed experiments. T.R., J.Je., M.K., P.K., M.H., T.S., N.M., Q.F., Q.W., T.S.S., P.C., B.R.S. analysed and interpreted the data. T.R., P.C., B.R.S. wrote the manuscript. All authors approved the final version. 
medRxiv preprint doi: https://doi.org/10.1101/2021.10.31.21265722; this version posted November 1, 2021. The copyright holder for this preprint (which was not certified by peer review) is the author/funder, who has granted medRxiv a license to display the preprint in

All rights reserved. No reuse allowed without permission.

\section{Competing interests}

2

3 P.C. declares research funding from AstraZeneca, Novartis, Roche, Takeda, and advisory

4 board/lecture/educational fees from AstraZeneca, Boehringer Ingelheim, Chugai, Kite,

5 Novartis, Pfizer, Roche, and Takeda. M.R. reports receiving honoraria for lectures and

6 consultancy from AstraZeneca, Amgen, BMS, Boehringer-Ingelheim, Lilly, Merck, MSD,

7 Mirati, Novartis, Sanofi, Pfizer, Roche. K.F.R. reports payments or honoraria from Boehringer

8 Ingelheim and Astra Zeneca, Novartis, Roche, Chiesi Pharmaceuticals, Regeneron, Sanofi

9 and Berlin Chemie outside the submitted work. M. T. discloses honoraria from AstraZeneca,

10 Bristol-Myers Squibb, Boehringer Ingelheim, Celgene, Chugai, Lilly, MSD, Novartis, Pfizer,

11 Roche, Takeda, Sanofi, Beigene, GSK and research funding from AstraZeneca, Bristol-Myers

12 Squibb, Roche and Takeda. T.R., R.H., J.Je., S.H., P.K., M.K., M.H., T.S. J.F., J.Sk., D.N.,

13 A.D.M, J.C., B.R.S. are employees of Hummingbird Diagnostics and hold company stock

14 options. T.R., R.H., J.Je., T.S., B.R.S. are inventors of patent applications related to response 15 prediction fo immunotherapy submitted by Hummingbird Diagnostics. T.S.S. serves on the 16 scientific advisory board of Hummingbird Diagnostics. N.M. received consulting fees from Hummingbird Diagnostics. 
medRxiv preprint doi: https://doi.org/10.1101/2021.10.31.21265722; this version posted November 1 , 2021. The copyright holder for this preprint (which was not certified by peer review) is the author/funder, who has granted medRxiv a license to display the preprint in perpetuity.

All rights reserved. No reuse allowed without permission.

\section{References}

1. Reck, M. et al. Pembrolizumab versus Chemotherapy for PD-L1-Positive Non-Small-Cell Lung Cancer. New England Journal of Medicine 375, 1823-1833 (2016).

2. Garon, E. B. et al. Five-Year Overall Survival for Patients With Advanced Non-Small-Cell Lung Cancer Treated With Pembrolizumab: Results From the Phase I KEYNOTE-001 Study. Journal of clinical oncology : official journal of the American Society of Clinical Oncology 37, 2518-2527 (2019).

3. Brahmer, J. R. et al. The Society for Immunotherapy of Cancer consensus statement on immunotherapy for the treatment of non-small cell lung cancer (NSCLC). Journal for ImmunoTherapy of Cancer 6, 75 (2018).

4. Daniello, L. et al. Therapeutic and Prognostic Implications of Immune-Related Adverse Events in Advanced Non-Small-Cell Lung Cancer. Frontiers Oncol 11, 703893 (2021).

5. Champiat, S. et al. Hyperprogressive Disease Is a New Pattern of Progression in Cancer Patients Treated by Anti-PD-1/PD-L1. Clin Cancer Res 23, 1920-1928 (2017).

6. Doroshow, D. B. et al. PD-L1 as a biomarker of response to immune-checkpoint inhibitors. Nat Rev Clin Oncol 18, 345-362 (2021).

7. Planchard, D. et al. Metastatic non-small cell lung cancer: ESMO Clinical Practice Guidelines for diagnosis, treatment and follow-up † † Footnotes Approved by the ESMO Guidelines Committee: February 2002, last update September 2018. This publication supersedes the previously published version-Ann Oncol 2016; 27 (Suppl 5): v1-v27. Ann Oncol 29, iv192-iv237 (2018).

8. Carbone, D. P. et al. First-Line Nivolumab in Stage IV or Recurrent Non-Small-Cell Lung Cancer. New England Journal of Medicine 376, 2415-2426 (2017).

9. Schoenfeld, A. J. et al. Clinical and molecular correlates of PD-L1 expression in patients

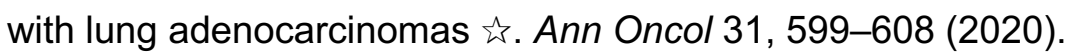

10. Tanizaki, J. et al. Peripheral Blood Biomarkers Associated with Clinical Outcome in NonSmall Cell Lung Cancer Patients Treated with Nivolumab. Journal of thoracic oncology: official publication of the International Association for the Study of Lung Cancer 13, 97-105 (2018).

11. Wu, T. D. et al. Peripheral T cell expansion predicts tumour infiltration and clinical response. Nature 579, 274-278 (2020).

12. Krieg, C. et al. High-dimensional single-cell analysis predicts response to anti-PD-1 immunotherapy. Nature medicine 24, 144-153 (2018).

13. Bartel, D. P. Metazoan MicroRNAs. Cell 173, 20-51 (2018).

14. Mehta, A. \& Baltimore, D. MicroRNAs as regulatory elements in immune system logic. Nature Reviews Immunology 16, 279-294 (2016). 
medRxiv preprint doi: https://doi.org/10.1101/2021.10.31.21265722; this version posted November 1 , 2021. The copyright holder for this preprint (which was not certified by peer review) is the author/funder, who has granted medRxiv a license to display the preprint in All rights reserved. No reuse allowed without permission.

15. Rainen, L. et al. Stabilization of mRNA expression in whole blood samples. Clinical Chemistry 48, 1883-1890 (2002).

16. Fuchs, R. T., Sun, Z., Zhuang, F. \& Robb, G. B. Bias in Ligation-Based Small RNA Sequencing Library Construction Is Determined by Adaptor and RNA Structure. Plos One 10, e0126049 (2015).

17. Hafner, M. et al. RNA-ligase-dependent biases in miRNA representation in deepsequenced small RNA cDNA libraries. Rna 17, 1697-1712 (2011).

18. Shukla, S. et al. Development of a RNA-Seq Based Prognostic Signature in Lung Adenocarcinoma. J Natl Cancer I 109, djw200 (2016).

19. Pölsterl, S. scikit-survival: A Library for Time-to-Event Analysis Built on Top of scikitlearn. Journal of Machine Learning Research 21, 1-6 (2020).

20. Davis, A. A. \& Patel, V. G. The role of PD-L1 expression as a predictive biomarker: an analysis of all US Food and Drug Administration (FDA) approvals of immune checkpoint inhibitors. J Immunother Cancer 7, 278 (2019).

21. Agarwal, V., Bell, G. W., Nam, J. W. \& Bartel, D. P. Predicting effective microRNA target sites in mammalian mRNAs. eLife (2015) doi:10.7554/elife.05005.

22. Kanehisa, M., Furumichi, M., Tanabe, M., Sato, Y. \& Morishima, K. KEGG: new perspectives on genomes, pathways, diseases and drugs. Nucleic Acids Res 45, D353D361 (2017).

23. Stutvoet, T. S. et al. MAPK pathway activity plays a key role in PD-L1 expression of lung adenocarcinoma cells. J Pathology 249, 52-64 (2019).

24. Hwang, S. et al. Immune gene signatures for predicting durable clinical benefit of antiPD-1 immunotherapy in patients with non-small cell lung cancer. Sci Rep-uk 10, 643 (2020).

25. Jiang, P. et al. Signatures of $T$ cell dysfunction and exclusion predict cancer immunotherapy response. Nat Med 24, 1550-1558 (2018).

26. Auslander, N. et al. Robust prediction of response to immune checkpoint blockade therapy in metastatic melanoma. Nat Med 24, 1545-1549 (2018).

27. Ayers, M. et al. IFN- $\gamma-$ related mRNA profile predicts clinical response to PD-1 blockade. J Clin Invest 127, 2930-2940 (2017).

28. Christopoulos, P. et al. Large cell neuroendocrine lung carcinoma induces peripheral Tcell repertoire alterations with predictive and prognostic significance. Lung Cancer 119, 4855 (2018).

29. Gros, A. et al. Prospective identification of neoantigen-specific lymphocytes in the peripheral blood of melanoma patients. Nat Med 22, 433-438 (2016).

30. Zilionis, R. et al. Single-Cell Transcriptomics of Human and Mouse Lung Cancers Reveals Conserved Myeloid Populations across Individuals and Species. Immunity 50 , 1317-1334.e10 (2019). 
medRxiv preprint doi: https://doi.org/10.1101/2021.10.31.21265722; this version posted November 1 , 2021. The copyright holder for this preprint (which was not certified by peer review) is the author/funder, who has granted medRxiv a license to display the preprint in perpetuity.

All rights reserved. No reuse allowed without permission.

31. Engblom, C., Pfirschke, C. \& Pittet, M. J. The role of myeloid cells in cancer therapies. Nature reviews. Cancer 16, 447-462 (2016).

32. He, G. et al. Peritumoural neutrophils negatively regulate adaptive immunity via the PDL1/PD-1 signalling pathway in hepatocellular carcinoma. Journal of experimental \& clinical cancer research : CR 34, 141-11 (2015).

33. Ballbach, M. et al. Expression of checkpoint molecules on myeloid-derived suppressor cells. Immunol Lett 192, 1-6 (2017).

34. Huber, V. et al. Tumor-derived microRNAs induce myeloid suppressor cells and predict immunotherapy resistance in melanoma. J Clin Invest 128, 5505-5516 (2018).

35. Best, M. G. et al. Swarm Intelligence-Enhanced Detection of Non- Small-Cell Lung Cancer Using Tumor-Educated Platelets. Cancer cell 32, 238-252.e9 (2017).

36. Best, M. G. et al. RNA-Seq of Tumor-Educated Platelets Enables Blood-Based PanCancer, Multiclass, and Molecular Pathway Cancer Diagnostics. Cancer Cell 28, 666-676 (2015).

37. Nilsson, R. J. A. et al. Blood platelets contain tumor-derived RNA biomarkers. Blood 118, 3680-3683 (2011).

38. Gandhi, L. et al. Pembrolizumab plus Chemotherapy in Metastatic Non-Small-Cell Lung Cancer. New Engl J Med 378, 2078-2092 (2018).

39. Mountzios, G. et al. Association of the advanced lung cancer inflammation index (ALI) with immune checkpoint inhibitor efficacy in patients with advanced non-small-cell lung cancer. Esmo Open 6, 100254 (2021).

40. Paz-Ares, L. et al. LBA80Pembrolizumab (pembro) plus platinum-based chemotherapy (chemo) for metastatic NSCLC: Tissue TMB (tTMB) and outcomes in KEYNOTE-021, 189, and 407. Ann Oncol 30, v917-v918 (2019).

41. Wessels, S. et al. Comprehensive serial biobanking in advanced NSCLC: feasibility, challenges and perspectives. Trans/ Lung Cancer Res 9, 1000-1014 (2020).

42. Travis, W. D. et al. The 2015 World Health Organization Classification of Lung Tumors Impact of Genetic, Clinical and Radiologic Advances Since the 2004 Classification. J Thorac Oncol 10, 1243-1260 (2015).

43. Volckmar, A. et al. Combined targeted DNA and RNA sequencing of advanced NSCLC in routine molecular diagnostics: Analysis of the first 3,000 Heidelberg cases. Int $J$ Cancer 145, 649-661 (2019).

44. Hanna, N. H. et al. Therapy for Stage IV Non-Small-Cell Lung Cancer Without Driver Alterations: ASCO and $\mathrm{OH}$ (CCO) Joint Guideline Update. J Clin Oncol 38, 1608-1632 (2020).

45. Davidson-Pilon, C. et al. CamDavidsonPilon/lifelines: 0.26.0. (2021) doi:10.5281/zenodo.4816284. 
medRxiv preprint doi: https://doi.org/10.1101/2021.10.31.21265722; this version posted November 1 , 2021. The copyright holder for this preprint (which was not certified by peer review) is the author/funder, who has granted medRxiv a license to display the preprint in

All rights reserved. No reuse allowed without permission.

1 46. Witten, D. M. \& Tibshirani, R. Survival analysis with high-dimensional covariates. Stat

2 Methods Med Res 19, 29-51 (2010).

3 47. Pedregosa, F. et al. Scikit-learn: Machine Learning in Python. Arxiv (2012).

4 48. Hu, Z. et al. Serum MicroRNA Signatures Identified in a Genome-Wide Serum MicroRNA

5 Expression Profiling Predict Survival of Non-Small-Cell Lung Cancer. J Clin Oncol 28,

$61721-1726(2010)$.

7 49. Cho, J. Y. et al. Gene Expression Signature-Based Prognostic Risk Score in Gastric

8 Cancer. Clin Cancer Res 17, 1850-1857 (2011).

9 50. Yu, S.-L. et al. MicroRNA Signature Predicts Survival and Relapse in Lung Cancer.

10 Cancer Cell 13, 48-57 (2008).

11 51. Baron, U. et al. Epigenetic immune cell counting in human blood samples for

12 immunodiagnostics. Science translational medicine 10, eaan3508 (2018).

13 52. Langmead, B., Trapnell, C., Pop, M. \& Salzberg, S. L. Ultrafast and memory-efficient 14 alignment of short DNA sequences to the human genome. Genome Biol 10, R25 (2009).

15 53. Kozomara, A., Birgaoanu, M. \& Griffiths-Jones, S. miRBase: from microRNA sequences 16 to function. Nucleic Acids Res 47, gky1141- (2018).

17 54. Waskom, M. et al. mwaskom/seaborn: v0.8.1 (September 2017). (2017)

18 doi:10.5281/zenodo.883859.

19 55. Yu, G., Wang, L.-G., Han, Y. \& He, Q.-Y. clusterProfiler: an R Package for Comparing

20 Biological Themes Among Gene Clusters. Omics J Integr Biology 16, 284-287 (2012). 
medRxiv preprint doi: https://doi.org/10.1101/2021.10.31.21265722; this version posted November 1 , 2021. The copyright holder for this preprint (which was not certified by peer review) is the author/funder, who has granted medRxiv a license to display the preprint in perpetuity.

All rights reserved. No reuse allowed without permission.

Table 1 | Clinical Characteristics of Patient Cohorts

2

Treatment
Characteristic
Site
Heidelberg
Großhansdorf
Sex, no. (\%)
Male
Female
Age at enrollment, yr
Mean \pm SD
Median (range)
Histological Subtype, no. (\%)
Adenocarcinoma
Squamous cell carcinoma
Other
ECOG performance status, no. (\%)
0
1
2
3
NA
Smoking status, no. (\%)
Never
Former
Current
Therapy, no. (\%)
Nivolumab
Pembrolizumab
Platinum doublet + Pembrolizumab
Therapy Line, no. (\%)
1
2
3
$>3$
PD-L1 TPS, no. \%
1-50

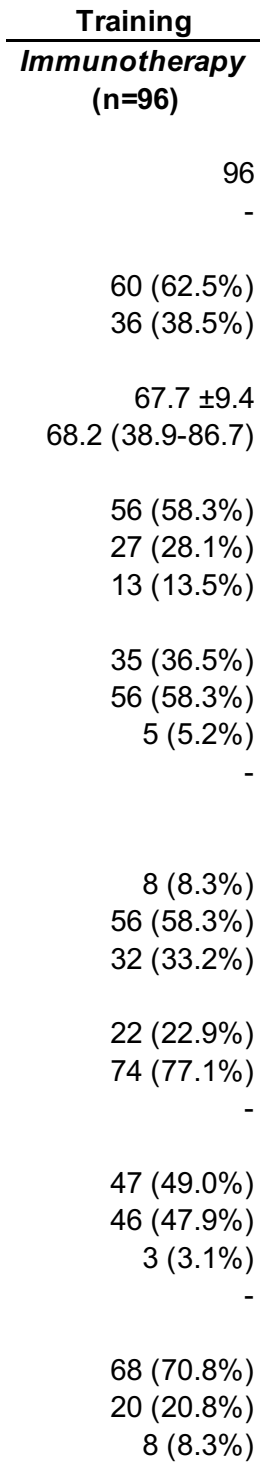

Independent Validation Immunotherapy

$(n=99)$

Control

Immunochemotherapy

$(n=139)$

96

84

15

$64(64.6 \%)$

$35(35.4 \%)$

$65.3 \pm 9.1$

$66.4(33.5-87.0)$

$56(56.6 \%)$

$33(33.3 \%)$

$10(10.1 \%)$

37 (37.4\%)

$52(52.5 \%)$

$5(5.1 \%)$

$1(1.0 \%)$

$4(4.0 \%)$

$5(5.1 \%)$

$56(56.6 \%)$

$38(38.4 \%)$

$40(40.4 \%)$

$59(59.6 \%)$

$36(36.4 \%)$

$43(43.4 \%)$

$13(13.1 \%)$

$7(7.1 \%)$

56 (56.6\%)

$27(27.3 \%)$

$16(16.2 \%)$
$139(100 \%)$

$93(66.9 \%)$

$46(33.1 \%)$

$64.8 \pm 9.0$

$64.9(37.6-84.8)$

$106(76.3 \%)$

$18(12.9 \%)$

$15(10.8 \%)$

$56(40.3 \%)$

$79(56.8 \%)$

$3(2.2 \%)$

$1(0.7 \%)$

$12(8.6 \%)$

$74(53.2 \%)$

$53(38.1 \%)$

$124(89.2 \%)$

$15(10.8 \%)$

$31(22.3 \%)$

$38(27.3 \%)$

$70(50.4 \%)$ 
medRxiv preprint doi: https://doi.org/10.1101/2021.10.31.21265722; this version posted November 1, 2021. The copyright holder for this preprint (which was not certified by peer review) is the author/funder, who has granted medRxiv a license to display the preprint in perpetuity.

All rights reserved. No reuse allowed without permission.

Table 2 | Univariable and multivariable Cox regression analysis of miRisk and clinical covariates

3

Overall survival

\section{Covariate}

PD-L1 ( $\leq 50 \%)$

ECOG $(>0)$

Gender (male vs female)

Age ( $>75$ years)

Substance (Pembro vs Nivo)

Histology (Non-adeno vs adeno)

Smoking status (ever smoker vs other)

ANC (>7.5)

ALC (>1)

miRisk (high vs low)
Therapy line incl. $<$ IV $(>2)$

\begin{tabular}{lcl}
\multicolumn{3}{c}{ Univariable Analysis } \\
\hline HR & $\mathbf{9 5 \%} \mathbf{C l}$ & P-value \\
1.70 & $0.97-3.00$ & 0.066 \\
2.82 & $1.47-5.41$ & 0.002 \\
1.07 & $0.60-1.93$ & 0.816 \\
1.66 & $0.85-3.24$ & 0.141 \\
1.36 & $0.73-2.54$ & 0.327 \\
0.68 & $0.39-1.19$ & 0.176 \\
1.63 & $0.93-2.85$ & 0.088 \\
1.92 & $0.46-7.96$ & 0.367 \\
1.98 & $1.08-3.62$ & 0.027 \\
0.57 & $0.32-0.99$ & 0.047 \\
2.47 & $1.36-4.48$ & 0.003
\end{tabular}

4

5

6

7

\begin{tabular}{lcl}
\multicolumn{3}{c}{ Multivariable Analysis } \\
\hline HR & $\mathbf{9 5 \%} \mathbf{C l}$ & P-value \\
1.85 & $0.58-5.93$ & 0.30 \\
4.61 & $2.21-9.59$ & 0.00 \\
0.79 & $0.42-1.49$ & 0.47 \\
1.84 & $0.88-3.86$ & 0.11 \\
1.31 & $0.67-2.55$ & 0.43 \\
1.36 & $0.44-4.25$ & 0.59 \\
1.65 & $0.84-3.24$ & 0.15 \\
4.62 & $1.00-21.42$ & 0.05 \\
1.07 & $0.54-2.11$ & 0.86 \\
0.69 & $0.39-1.24$ & 0.22 \\
2.40 & $1.12-5.14$ & 0.02
\end{tabular}


medRxiv preprint doi: https://doi.org/10.1101/2021.10.31.21265722; this version posted November 1 , 2021. The copyright holder for this preprint (which was not certified by peer review) is the author/funder, who has granted medRxiv a license to display the preprint in

\section{Figure 1}

a

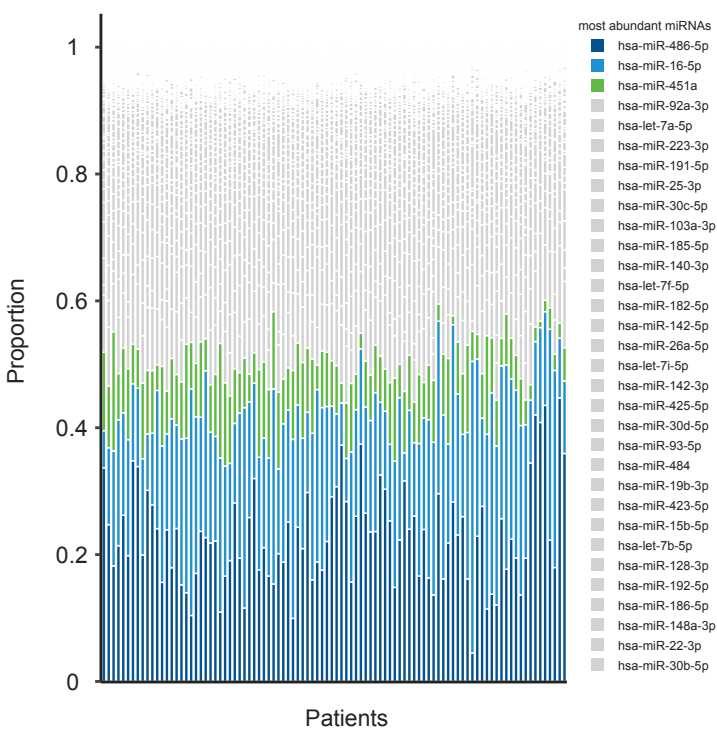

C

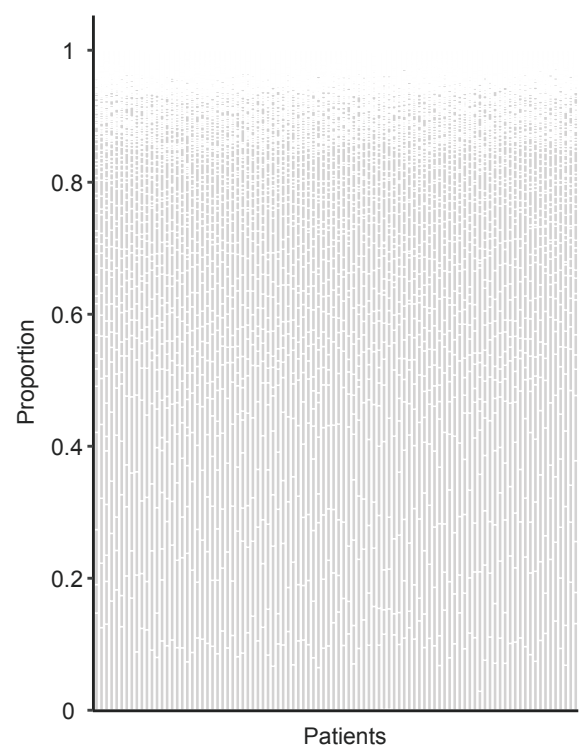

b

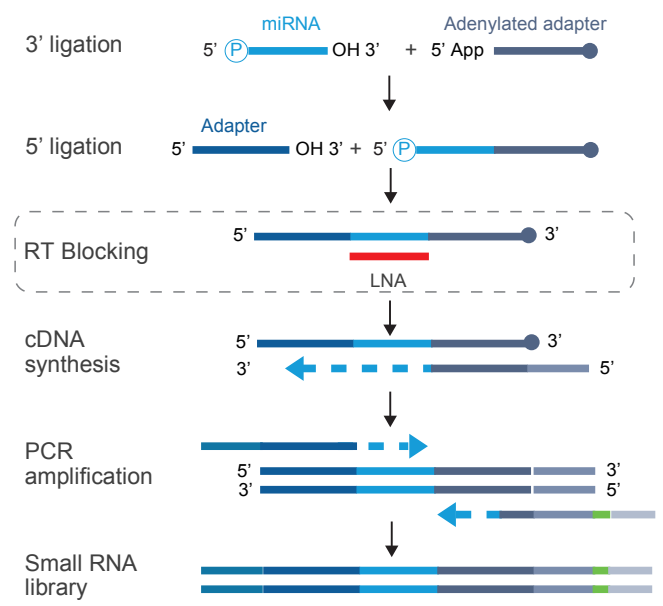

d

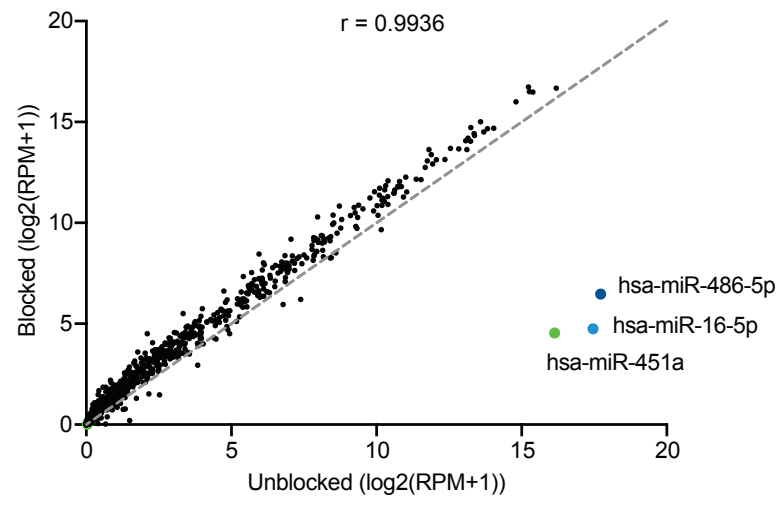

2 Figure 1 | Whole blood small RNA sequencing pipeline with blocking of highly abundant

3 miRNAs. a Sequencing of whole blood from 96 NSCLC patients revealed that $~ 50 \%$ of reads

4 per patient map to hsa-miR-486-5p, hsa-miR-16-5p, and hsa-miR-451a. b The standard

5 miRNA library preparation protocol has been modified to block the incorporation of specific

6 miRNAs using antisense locked nucleic acid (LNA) oligonucleotides that block the reverse

7 transcription of target miRNAs. c The three blocking target miRNAs have been almost entirely

8 eliminated from the sequencing libraries therefore increasing the sequencing bandwidth

9 available for the detection of other miRNAs. $\mathbf{d}$ Mean miRNA expression following sequencing

10 of unblocked or blocked libraries reveals specific depletion of the on-target miRNAs whilst

11 maintaining a high correlation between the expression values of all other features $(r=0.99)$. 
medRxiv preprint doi: https://doi.org/10.1101/2021.10.31.21265722; this version posted November 1 , 2021. The copyright holder for this preprint (which was not certified by peer review) is the author/funder, who has granted medRxiv a license to display the preprint in perpetuity.

All rights reserved. No reuse allowed without permission.

1

a

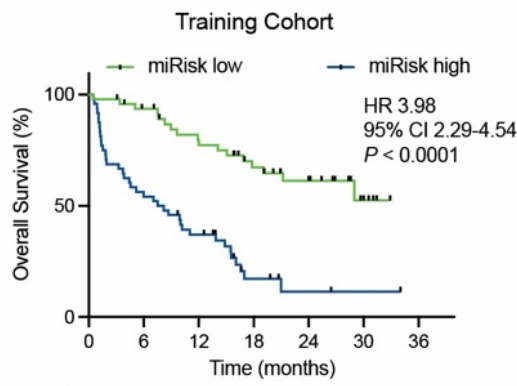

No. at risk

high risk $\begin{array}{llllll}48 & 26 & 17 & 5 & 2 & 1\end{array}$

$\begin{array}{lllllll}\text { low risk } & 48 & 42 & 34 & 25 & 18 & 5\end{array}$

d

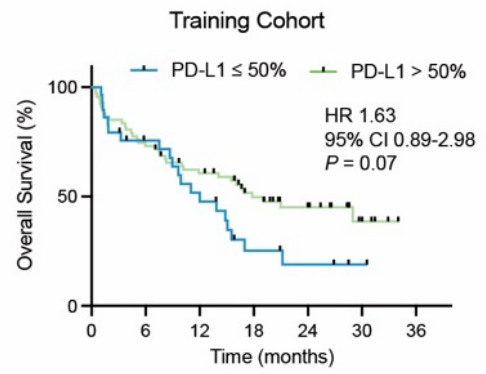

No. at risk

$\begin{array}{llllll}>50 \% & 67 & 49 & 38 & 25 & 17\end{array}$

g

Training Cohort

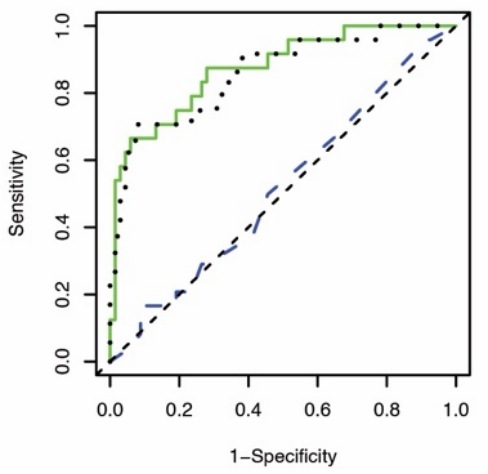

— miRisk AUC 0.873 (0.776-0.947)

- PD-L1 AUC $0.516(0.382-0.648)$

. miRisk + PD-L1 AUC $0.860(0.757-0.943)$

\section{Figure 2}

b

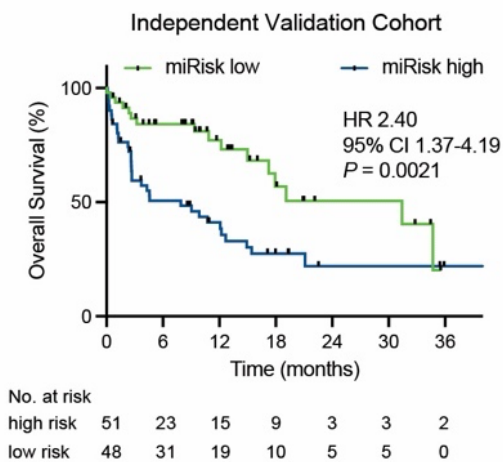

e

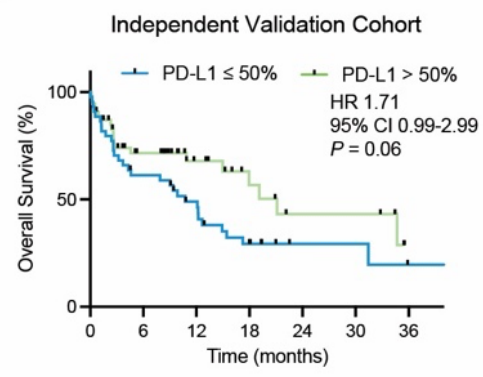

No. at risk

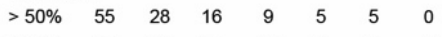

h

Independent Validation Cohort

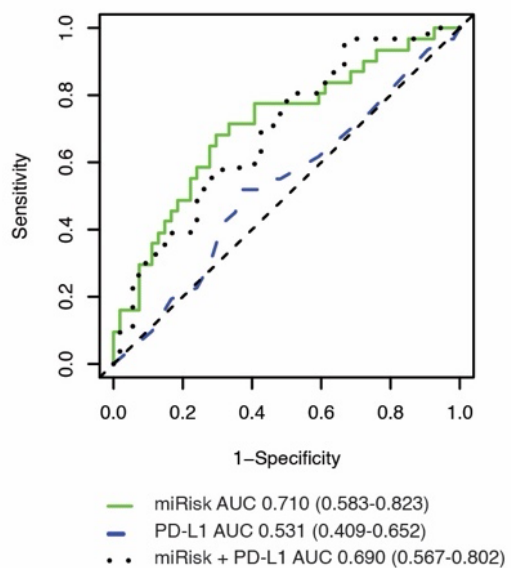

C

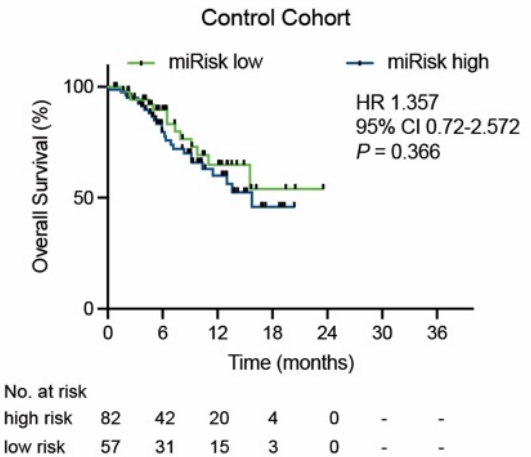

f

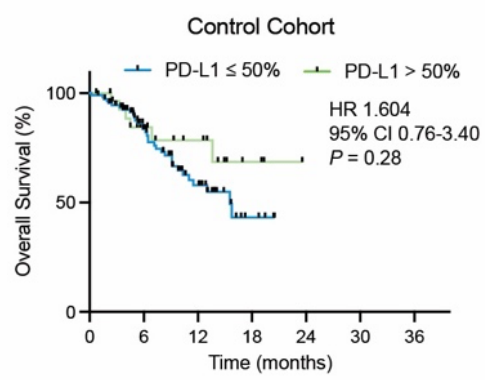

No. at risk

$\begin{array}{llllll}>50 \% & 29 & 15 & 10 & 3 & 0\end{array}$

$\begin{array}{llllll}\leq 50 \% & 110 & 58 & 25 & 4 & 3\end{array}$

i

Control Cohort

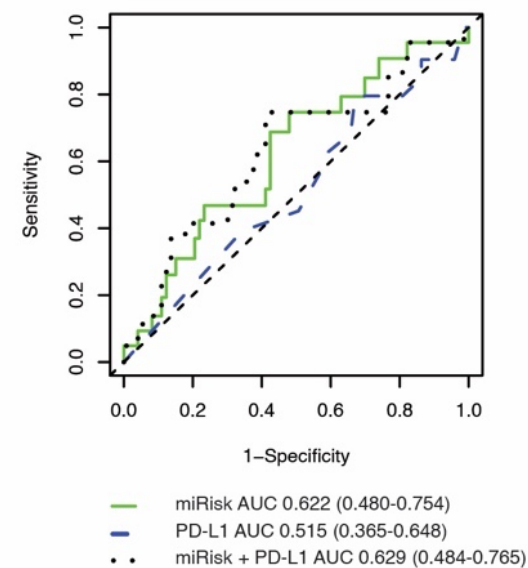

2 Figure 2 | Overall survival of NSCLC patients stratified by miRisk score and PD-L1 TPS.

3 a-c Comparison of OS between low/high miRisk score groups in the training $(n=96)$,

4 independent validation ( $n=99)$, and the control cohorts $(n=139)$. Significant differences in OS

5 are observed in the training and independent validation cohorts but not the control cohort. $d$ -

6 e Comparison of OS between patients stratified by PD-L1 TPS in the training $(n=96)$,

7 independent validation $(n=99)$, and the control cohorts $(n=139)$. The differences in OS do not

8 reach significance in any cohort. Hazard ratios (HR) and 95\% confidence intervals were

9 calculated using a univariable Cox regression analysis; $P$-values were calculated using the

10 log-rank test. All statistical analyses were two-sided. g-h Time dependent ROC curves (6

11 months) in the training, independent validation and control cohorts, as determined by the

12 miRisk score, PD-L1 TPS or a model incorporating the miRisk miRNAs + PD-L1 TPS. 
medRxiv preprint doi: https://doi.org/10.1101/2021.10.31.21265722; this version posted November 1, 2021. The copyright holder for this preprint (which was not certified by peer review) is the author/funder, who has granted medRxiv a license to display the preprint in

All rights reserved. No reuse allowed without permission.

1

a

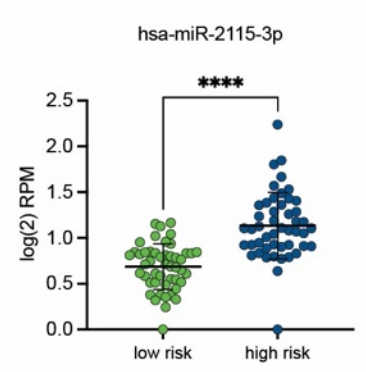

f

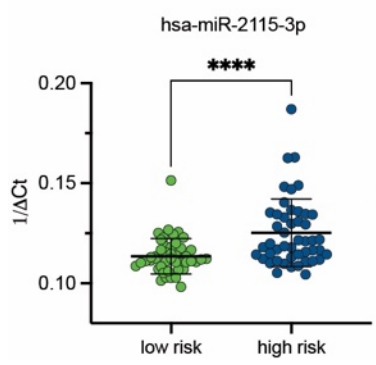

b

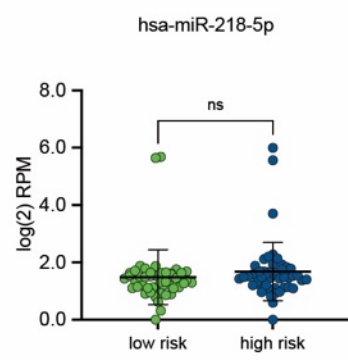

g

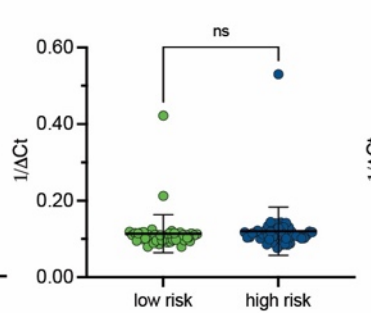

Figure 3

C

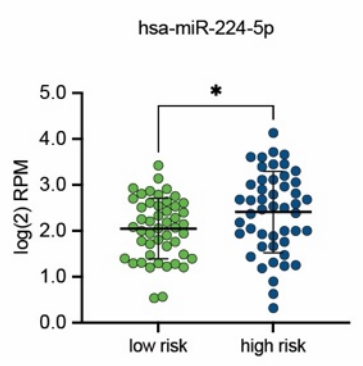

h

hsa-miR-224-5p

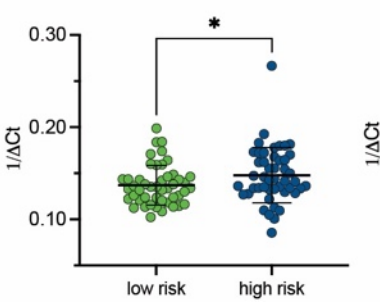

d

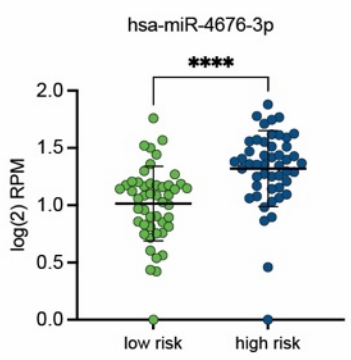

i e

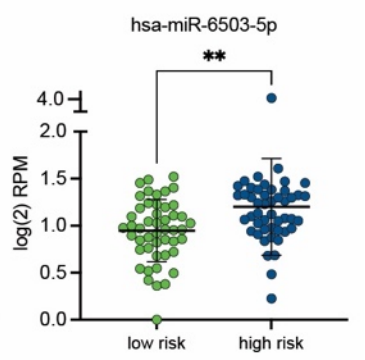

j

hsa-miR-6503-3p
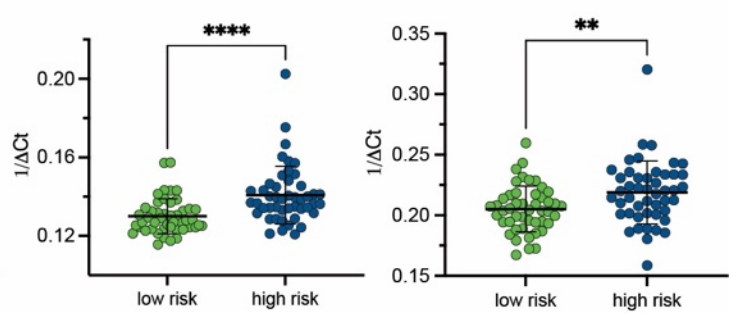

Figure 3 | miRisk miRNA expression in low-risk and high-risk patients. a-e Relative

4 expression levels of the 5 miRisk miRNAs between low-risk and high-risk patients measured

5 by small RNA sequencing. $f-j$ Relative expression levels of the 5 miRisk miRNAs between

6 low-risk and high-risk patients measured by qRT-PCR. The mean expression of triplicate

7 measurements is shown. qRT-PCR expression was normalized according to the $\Delta$ Ct method

8 ( $\mathrm{Ct}_{\text {miRNA of interest }}-\mathrm{Ct}_{\text {mean }}$ of HK miRNAs $)$. All statistical tests were two-tailed unpaired tests. Error

9 bars denote standard deviation. RPM $=$ reads per million. ${ }^{*}=P$-value $<0.05,{ }^{* *}=P$-value $<$

$100.005,{ }^{* * *}=P$-value $<0.0005,{ }^{* * * *}=P$-value $<0.00005$, ns $=$ not significant. 
medRxiv preprint doi: https://doi.org/10.1101/2021.10.31.21265722; this version posted November 1, 2021. The copyright holder for this preprint (which was not certified by peer review) is the author/funder, who has granted medRxiv a license to display the preprint in perpetuity.

All rights reserved. No reuse allowed without permission.

Figure 4

a

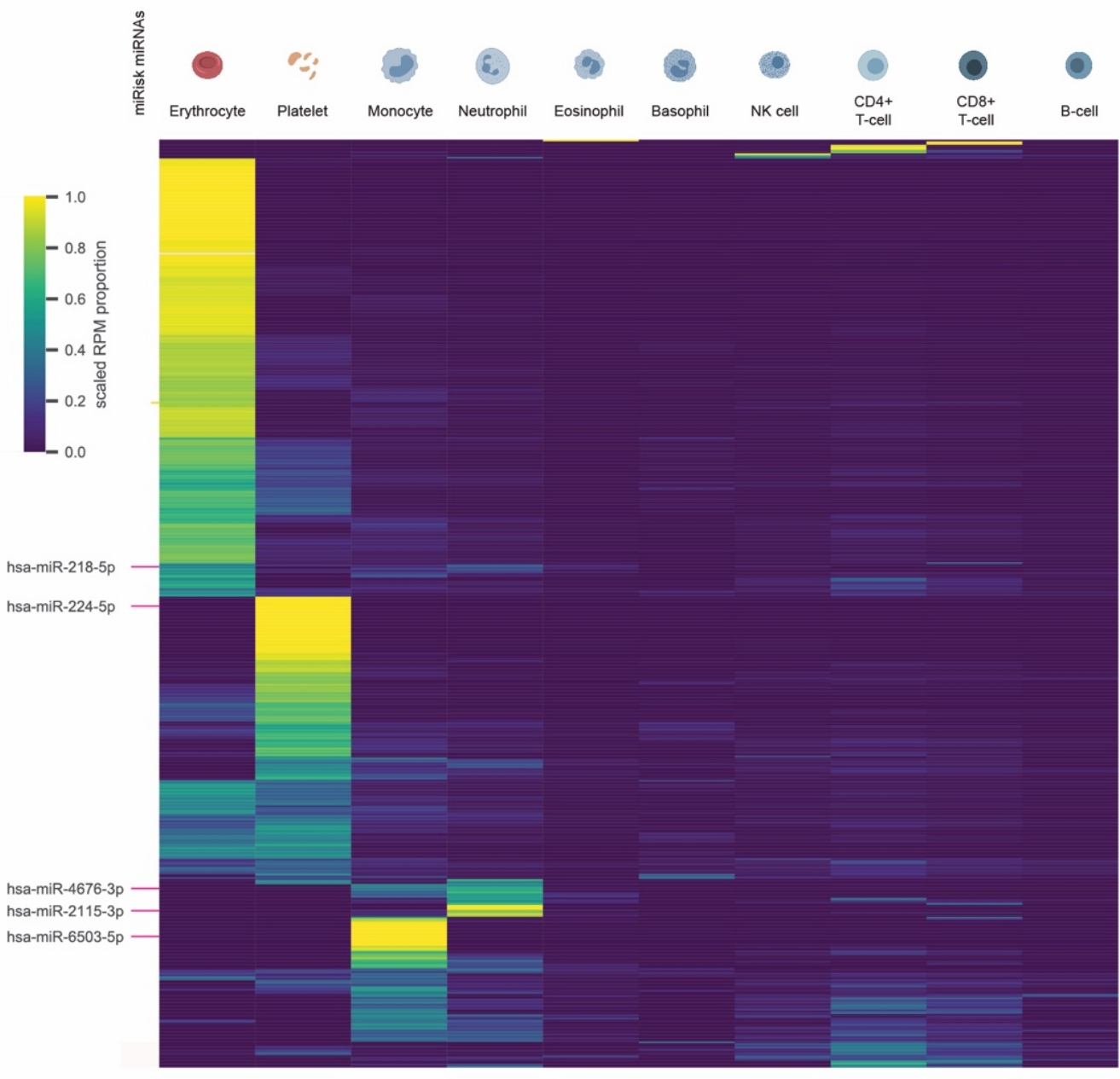

b

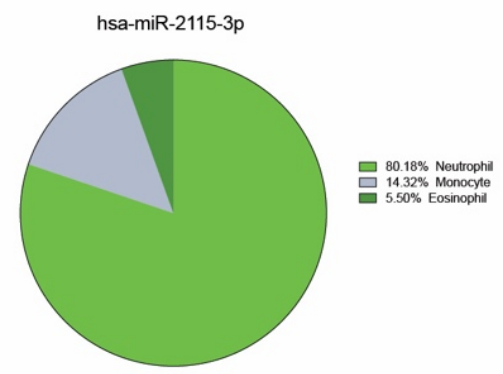

e
C

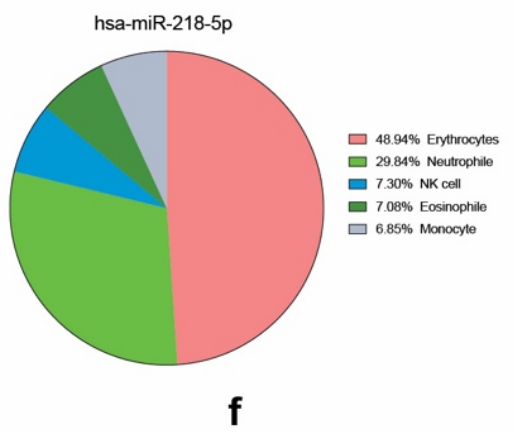

d

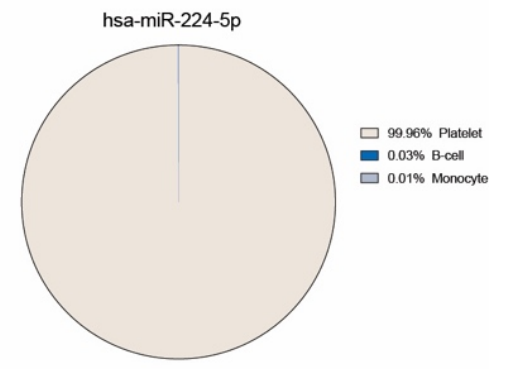

hsa-miR-4676-3p

ㅁ $62.06 \%$ Monocyte

口 $37.94 \%$ Neutrophil
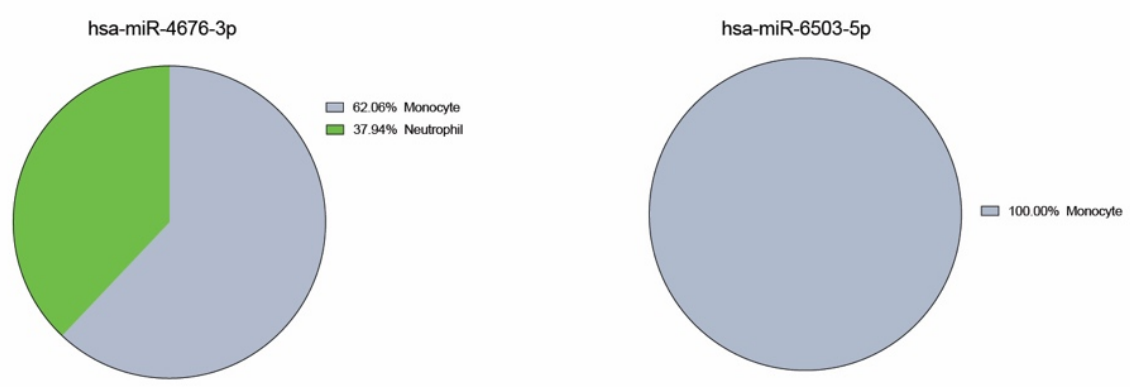
medRxiv preprint doi: https://doi.org/10.1101/2021.10.31.21265722; this version posted November 1, 2021. The copyright holder for this preprint (which was not certified by peer review) is the author/funder, who has granted medRxiv a license to display the preprint in All rights reserved. No reuse allowed without permission.

1 Figure 4 | Cellular origin of miRisk miRNAs in peripheral whole blood. a Relative 2 distribution of PAXgene detected miRNAs across 10 purified cell types. The 5 miRisk miRNAs 3 are indicated. b-f The relative contributions and cellular origin of the 5 miRisk miRNAs. miRNA 4 RPM values were scaled by cell type specific small RNA content per cell and abundance in 5 blood. Per miRNA the scaled values of all measured cell types were indexed to $100 \%$. RPM 6 = reads per million. 